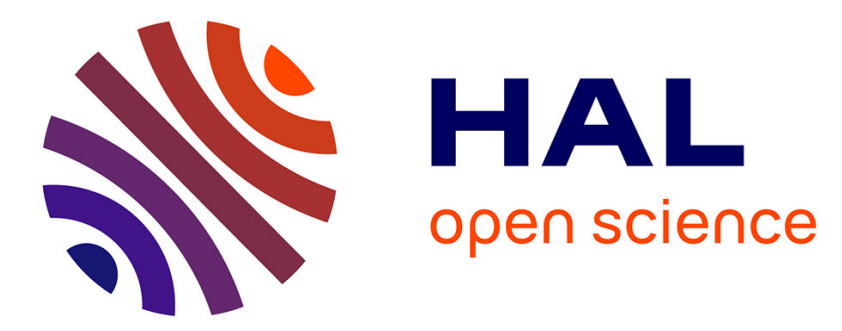

\title{
Comparative study on the bioaccumulation and biotransformation of arsenic by some northeastern Atlantic and northwestern Mediterranean sponges
}

Anna Maria Orani, Aurélie Barats, Wendy Zitte, Christine Morrow, Olivier P

Thomas

\section{To cite this version:}

Anna Maria Orani, Aurélie Barats, Wendy Zitte, Christine Morrow, Olivier P Thomas. Comparative study on the bioaccumulation and biotransformation of arsenic by some northeastern Atlantic and northwestern Mediterranean sponges. Chemosphere, 2018, 201, pp.826-839.

10.1016/j.chemosphere.2018.03.078 . hal-01852764

\author{
HAL Id: hal-01852764 \\ https://hal.science/hal-01852764
}

Submitted on 28 Jan 2020

HAL is a multi-disciplinary open access archive for the deposit and dissemination of scientific research documents, whether they are published or not. The documents may come from teaching and research institutions in France or abroad, or from public or private research centers.
L'archive ouverte pluridisciplinaire HAL, est destinée au dépôt et à la diffusion de documents scientifiques de niveau recherche, publiés ou non, émanant des établissements d'enseignement et de recherche français ou étrangers, des laboratoires publics ou privés. 


\title{
Comparative study on the bioaccumulation and biotransformation of arsenic by some Northeastern Atlantic and Northwestern Mediterranean sponges
}

\author{
Anna Maria Orani * ${ }^{a, c}$, Aurélie Barats ${ }^{a}$, Wendy Zitte ${ }^{a}$, Christine Morrow ${ }^{b}$, Olivier P. Thomas ${ }^{b}$ \\ a Université Nice Sophia Antipolis, CNRS, IRD, Observatoire de la Côte d'Azur, Géoazur, UMR 7329, 250 rue Albert Einstein, \\ Sophia Antipolis 06560 Valbonne, France \\ b National University of Ireland Galway, Marine Biodiscovery, School of Chemistry, University Road, Galway, Ireland \\ c International Atomic Energy Agency, Environment Laboratories, 4 Quai Antoine 1er, MC 9800, Monaco \\ *corresponding author: a.m.orani@iaea.org
}

\section{Abstract}

The bioaccumulation and biotransformation of arsenic (As) were studied in six representative marine sponges from the French Mediterranean and Irish Atlantic coasts. Methodologies were carefully optimized in one of the species on Haliclona fulva sponges for two critical steps: the sample mineralization for total As analysis by ICP-MS and the extraction of As species for HPLC-ICP-MS analysis. During the optimization, extractions performed with $0.6 \mathrm{~mol} \mathrm{~L}^{-1} \mathrm{H}_{3} \mathrm{PO}_{4}$ were shown to be the most efficient. Extraction recovery of $81 \%$ was obtained which represents the best results obtained until now in sponge samples. Total As analyses and As speciation were performed on certified reference materials and allow confirming the measurement quality both during the the sample preparation and analysis. Additionally, this study represents an environmental survey demonstrating a high variability of total As concentrations among the different species, probably related to different physiological or microbial features. As speciation results showed the predominance of arsenobetaine (AsB) regardless of the sponge species, as well as the occurrence of low amounts of dimethylarsinic acid $(\mathrm{DMA})$, arsenate $(\mathrm{As}(+\mathrm{V}))$, and unknown As species in some samples. The process responsible for As transformation in sponges is most likely related to sponges metabolism itself or the action of symbiont organisms. AsB is supposed to be implied in the protection against osmolytic stress. This study demonstrates the ability of sponges to accumulate and bio-transform As, proving that sponges are relevant bio-monitors for As contamination in the marine environment, and potential tools in environmental bioremediation.

Keywords: marine sponges; biomonitor; arsenic bioaccumulation; arsenic speciation; bioremediation 


\section{Introduction}

Arsenic (As) is a ubiquitous element that ranks $20^{\text {th }}$ in abundance in the earth's crust $\left(1.5-3 \mathrm{mg} \mathrm{kg}{ }^{-1}\right)$. This metalloid occurs naturally in the environment, and it is also provided by some anthropogenic activities (Mandal and Suzuki, 2002). As is recognized to be toxic and one of the six most preoccupying pollutants on earth together with lead, mercury, chromium, some radionuclides and pesticides. The understanding of As cycle in marine ecosystem remains a challenging task since arsenic often occurs at very low concentrations (around 1 $\mu \mathrm{g} \mathrm{L}^{-1}$ in seawater) and under one of the most toxic inorganic species $(\mathrm{As}(+\mathrm{V}))$ (Cabon and Cabon, 2000). Within this context, there is a clear need to gain a better understanding of the As cycle in the marine environment.

The quantification of total As in marine organisms and especially in seafood has been performed in numerous studies (Phillips, 1990; Kucuksezgin et al., 2014; Wu et al., 2014; Olmedo et al., 2013), but rarely in marine invertebrates. Among marine invertebrates, sponges are sessile filter feeders, capable of filtering every day a volume of seawater up to 50000 times that of their body (Weisz et al., 2008). They have been recognized as excellent bio-monitors for trace element pollution (Perez et al., 2005; Cebrian et al., 2007) as they are capable to accumulate trace elements at concentrations higher than bivalves (Patel et al., 1985; Negri et al., 2006; Padovan et al., 2012). On hard substrata, sponges are one of the top spatial competitors (Bell, 2008) and have recently been proposed as model organisms to monitor aquatic contamination, in addition to the already existing and well known "Mussel Watch Program" (Genta-Jouve et al., 2012). The bioaccumulation of trace elements in sponges was suggested to differ according to sponge species and the element of interest (Batista et al., 2014; Mayzel et al., 2014; Cebrian et al., 2007; Patel et al., 1985). Only few studies focused on As bioaccumulation in sponges (Aly et al., 2013; Araújo et al., 2003; Batista et al., 2014; Denton et al., 2006; Keren et al., 2015; Keren et al., 2016; Keren et al., 2017; Padovan et al., 2012; Pan et al., 2011; Perez et al., 2005; Schaeffer et al., 2006; Shiomi et al., 1988; Vaskovsky et al., 1972; Venkateswara Rao et al., 2009; Yamaoka et al., 2001; Yamaoka et al., 2006). These studies revealed how As concentrations in sponges is variable, exceeding $100 \mathrm{mg} \mathrm{kg}^{-1}$ in some cases, and usually higher than in other marine organisms (generally $<10 \mathrm{mg} \mathrm{kg}^{-1}$ 
in fish, algae and shellfish) (Llorente-Mirandes et al., 2010). Sponges seem to accumulate more As than other marine organisms, which makes them suitable models for biomonitoring studies, as already proposed by Genta-Jouve et al., 2012. As accumulation was previously demonstrated to be strongly related to sponge orders or species; for instance higher in demosponges than in calcareous sponges (Yamaoka et al., 2001).

The determination of total As concentration is however not sufficient as As toxicity and biological impact depend directly on its chemical form, i.e. its speciation (Cullen and Reimer, 1989; Hughes, 2002; Sakurai, 2002) . Among arsenic species, inorganic arsenite $\mathrm{As}(+\mathrm{III})$ and arsenate $\mathrm{As}(+\mathrm{V})$ are the most toxic forms. These two inorganic forms are carcinogenic and cause damage to the respiratory, cardiovascular, nervous, and hematopoietic systems, as well as lesions to skin and liver (Pershagen, 1981). The methylated forms monomethylarsonic acid (MMA) and dimethylarsinic acid (DMA) are less toxic than the previously mentioned inorganic species, but they are recognized as cancer promoters (Brown et al., 1997) while arsenobetaine (AsB), the major species in marine animals, arsenocholine (AsC), trimethylarsine oxide (TMAO) and tetramethylarsonium ion (TMAs) are considered nontoxic (ATSDR, 2007). Other As species, like arsenosugars (AsS), often found in seafood and generally in marine organisms, have been recognized not to be acutely toxic; nevertheless a chronic toxicity is a possibility (Andrewes et al., 2004). The quantitation of the different As chemical forms, i.e. arsenic speciation, can be performed with different analytical techniques(Benramdane et al., 1999; Hsieh et al., 2010; Nearing et al., 2014 ; Tian et al., 2010). HPLC-ICP-MS represents the most used technique by far (Benramdane et al., 1999; Nearing et al., 2014) because this hyphenated technique combines a rapid, powerful and reproducible separation method with a very efficient detector due to its high sensitivity and large linear dynamic range (Beauchemin, 2008).

In most aquatic organisms, As speciation analysis has already revealed the occurrence of AsB, AsS, DMA and inorganic species. In freshwater organisms, the inorganic As(+III) species was reported as dominant for gastropods (Hong et al., 2014), two AsS species for microalgae, DMA for Anguilla japonica and more often AsB for other fish-species and crustaceans (Miyashita et al., 2009). AsB was suggested to contribute in a greater 
proportion of total As in marine organisms than in freshwater ones, which represents the major difference in As speciation between aquatic organisms (Schaeffer et al., 2006; Hong et al., 2014). AsB is reported as the most abundant As-species in several organisms, such as shrimps, bivalves, crabs and fishes (Lai et al., 1999; Schaeffer et al., 2006; Taylor et al., 2012; Caumette et al., 2012; Hong et al., 2014), whereas some AsS species can also be dominant in clams and mussels (Grotti et al., 2010; Taylor et al., 2012). The relative proportions of these two major As-compounds (AsB and AsS) would depend on the position of the organism in the food chain: the percentage of AsB normally increases through the food web, whereas the AsS fraction decreases (Grotti et al., 2010). Concerning sponges, the inorganic $A s(+V)$ specie was reported as dominant in freshwater sponges from the Danube River in Hungary (Schaeffer et al., 2006) whereas in Japanese and Philippine marine sponges, AsS and $A s B$ were found to be dominant, showing interesting variability among the studied species (Shiomi et al., 1988; Yamaoka et al., 2001; Yamaoka et al., 2006). Recently, the role of sponge-associated bacteria in As bioaccumulation was evaluated since bacteria are known as key contributors to important elemental cycling in sponges, specifically for carbon, nitrogen, sulfur as well as trace elements (Keren et al., 2015; Keren et al., 2016; Keren et al., 2017). The sponge symbiotic bacterium Entotheonella sp. was shown to constitute the Asaccumulating entity within the holobiont.

Considering the lack of studies on As speciation in marine sponges a deeper knowledge of As speciation in marine sponges is needed. In this work, a methodology was first developed for total As analyses by ICP-MS and As speciation by HPLC-ICP-MS in sponges. This approach was then applied to different sponge species collected in distinct marine environments. This study focused on different sampling sites located in the French Mediterranean coast, but also in the Irish Atlantic coast. These sites were characterized by different natural and anthropogenic As inputs offering thus the opportunity to study possible differences in As bioaccumulation and biotransformation related to the element availability.

\section{Materials and methods}




\subsection{Sampling and target species}

The sponge samples analyzed in this study were collected either by SCUBA diving in the French Mediterranean coast in the Villefranche-sur-Mer Bay, or in the Irish Atlantic coast shore in Greenisland and in the Killkieran Bay. The French sampling area is densely populated and a well-known tourist destination, especially in summer time. Greenisland is a large inlet in the Belfast Lough, at the western end is the city and the port of Belfast, which sits at the mouth of the Lagan River. The lough opens into the North Channel and connects Belfast to the Irish Sea. Kilkieran Bay is a large, complex inlet in southern Connemara, County Galway, on west coast of Ireland.

Initial sampling of specimens of the sponge Haliclona fulva was carried out in the Bay of Villefranche sur $\operatorname{Mer}\left(\mathrm{N} 43^{\circ} 41^{\prime} 59.0^{\prime \prime}, \mathrm{E} 07^{\circ} 19^{\prime} 31.5^{\prime \prime}\right)$ on January 2014 , in order to optimize the mineralization and extraction procedures for As analyses. Subsequent sampling was conducted in the Bay of Villefranche sur Mer on February and September 2016, in Killkieran Bay ( $53^{\circ} 21^{\prime} 22.625^{\prime \prime}, 09^{\circ} 42^{\prime} 17.153^{\prime \prime}$ ) in October 2016, and in

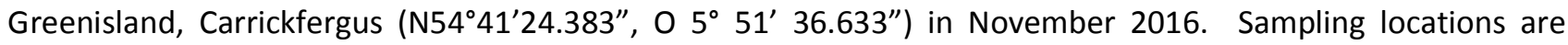
shown in Fig. 1A (supplementary information). At least, three specimens of each sponge species were collected from each sampling site and period. In order to minimize differences due to sponge ages, organisms of a similar size were chosen. In the Mediterranean coast, samples were collected between 5 and $40 \mathrm{~m}$ depth, whereas in Ireland, they were collected from intertidal areas.

The following sponge species were collected for 2 sampling dates in the Mediterranean coast: Acanthella acuta; Cymbaxinella ${ }^{p}$ damicornis; Chondrilla nucula and Haliclona fulva. From Greenisland and Killkieran Bay, the following species were collected: Halichondria panicea and Hymeniacidon perlevis (Fig. 2A, supplementary information). These species were selected because of their widespread occurrence but also for their different morphological characteristics (KeyToNature, 2015): 
a) Acanthella acuta (Class: Demospongiae, Order: Axinellida, Family: Dictyonellidae) is a small erect sponge with rather small oscules.

b) Cymbaxinella ${ }^{p}$ damicornis (Class: Demospongiae, Order: Axinellida, Family: Axinellidae, ${ }^{p}$ phylocode name), is a rather small, erectly branching sponge with short, compressed branches. Oscules are small and are located on the apices of the branches, the oscules are surrounded by a small triangular 'flap' of tissue. The genus Axinella is difficult to define on the basis of morphological characteristic but for the specie analyzed in this study the name Cymbaxinella damicornis was recently proposed by Gazave et al. (2010) following the phylocode.

c) Chondrilla nucula (Class: Demospongiae, Order: Chondrillida, Family: Chondrillidae) is amorphous, with globular lobes, or thickly incrusting, up to about $1 \mathrm{~cm}$ thick, spreading horizontally, with pronounced, deeply incised and lacunose, meandering lobes. The color is dark-brown to walnut-brown.

d) Haliclona fulva (Class: Demospongiae, Order: Haplosclerida, Family: Chalinidae), is a specimen with irregular and slightly hispid surface. The ectosomal and choanosomal skeletons have a regular, delicate, unispicular, and isotropic reticulation. Color is dark orange.

e) Halichondria panicea (Class: Demospongiae, Order: Suberitida, Family: Halichondriidae), is intertidal or shallow-subtidal, thickly encrusting, massive or occasionally branching, and presents typical volcanoeshaped oscular chimneys. The surfaces of this sponge are smooth, consistency firm, texture crumb-ofbread. These sponges are basically light orange-yellow or pale yellowish green.

f) Hymeniacidon perlevis (Class: Demospongiae, Order: Suberitida, Family: Halichondriidae), is one of the most common species along the Atlantic coasts of Western Europe. It is orange and has an irregular surface, often with lower or higher irregular projections. Oscules are inconspicuous.

Samples were kept frozen at $-20^{\circ} \mathrm{C}$. The sponge samples were then freeze-dried (Christ Martin ${ }^{\mathrm{TM}}$ Alpha $^{\text {TM }}$ 1-2 Ldplus) and ground in an agate mortar in order to obtain a homogeneous powder. Samples were transferred into PTFE pre-cleaned tubes and kept in a desiccator. 


\subsection{Sample preparation}

All solutions were prepared with doubly deionized water obtained from Millipore water purification system

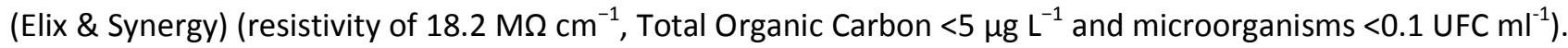
All PTFE and Teflon containers used for sample preparation and/or analysis were pre-cleaned using a procedure consisting of $24 \mathrm{~h}$ bath in $10 \% \mathrm{HNO}_{3}$ and careful rinsing with Milli-Q water. For total As quantification, samples were digested in a closed microwave system (Ethos One, Milestone) prior to ICP-MS analysis. The digestion program included a $20 \mathrm{~min}$ temperature ramp up to $180^{\circ} \mathrm{C}$ followed by $30 \mathrm{~min}$ isothermal step (power $2000 \mathrm{~W}$ ). An aliquot of dried sponge sample was weighted in Teflon reactors. Chemical reagents were added and the microwave digestion was carried out. The sample mass and the use of different chemical reagents were optimized within this study. The following chemical reagents were used: $\mathrm{HNO}_{3}($ Trace Metal Grade, 67 to 70\% w/w, Fisher Chemical), HF (Ultra Trace Elemental Analysis 47-51\% w/w, Optima, Fisher Chemical), $\mathrm{HCl}\left(\geq 30 \%\right.$, for trace analysis, Sigma-Aldrich) and $\mathrm{H}_{2} \mathrm{O}_{2}(\geq 30 \%$, for trace analysis, Sigma-Aldrich). The mineralized solution was then transferred to PE pre-cleaned tubes and gravimetrically diluted with Milli-Q water, up to a final volume of $50 \mathrm{~mL}$. All samples were further diluted 15 times in Milli-Q water prior to ICP-MS analysis. At least one procedural blank and one quality control Certified Reference Materials (CRM) were included in each digestion run and analyzed with the rest of the samples. The following CRMs were used in this study: TORT-2 (lobster hepatopancreas, Institute for Environmental Chemistry, National Research Council Canada, Ottawa, Canada), BCR-627 (tuna fish powder, Institute for Reference Materials and Measurements, Geel, Belgium) and MESS-2 (estuarine sediment, Institute for Environmental Chemistry, National Research Council Canada, Ottawa, Canada). These CRM were prepared and analyzed along with the vent samples as an assessment of analytical accuracy.

For As speciation, the extraction method was optimized using different chemicals and/or proportion: MilliQ water, methanol ( $\mathrm{MeOH}, \mathrm{HPLC}$ Plus, $\geq 99.9 \%$, Sigma-Aldrich) and $\mathrm{H}_{3} \mathrm{PO}_{4}$ ( $\geq 85$ wt. \% in $\mathrm{H}_{2} \mathrm{O}$, trace metals basis, Sigma-Aldrich). Extractions were performed the day before analyses and extracts were kept frozen during the 
night. Since no sponge CRM is available on the market, the extraction performances were evaluated using the certified reference material BCR-627 (certified for As speciation) and TORT-2. For sponge samples, extractions were performed at least 3 times for each species to account for intra-specie variability. $10 \mathrm{~mL}$ of the selected solvent were added to about $50 \mathrm{mg}$ of dried sample. The mixture was sonicated for one $\mathrm{h}$. The extracts were then filtered with a single-use syringe through single-use syringe filters $\left(0.45 \mu \mathrm{m}\right.$, Minisart ${ }^{\circledR} \mathrm{RC} 25$, Sartorius $)$ and gravimetrically diluted 10 times in Milli-Q water. The extracts were analyzed by HPLC-ICP-MS.

\subsection{Sample analyses}

A quadrupole ICP-MS (Elan DRCII, Perkin Elmer) was used as detection system for the determination of total As in sponge samples. ICP-MS operating parameters are summarized in Table $1 .{ }^{75}$ As isotope may be interfered in saline matrices by $\mathrm{Cl}\left(\right.$ by $\left.{ }^{40} \mathrm{Ar}^{35} \mathrm{Cl}^{+}\right)$. The most common way to remove these spectral interferences is using the following correction equation: $|(A s)=I(m / z=75)-3.127 \times|(m / z=77)+2.733 \times \mid(m / z=82)$ where I stands for intensity (Potot et al., 2012; Barats et al., 2014). This mathematical correction accounts for about possible polyatomic interferences $\left({ }^{40} \mathrm{Ar}^{35} \mathrm{Cl}^{+}\right.$or $\left.{ }^{40} \mathrm{Ar}^{37} \mathrm{Cl}^{+}\right)$as well as for the occurrence of selenium $\left({ }^{77,82} \mathrm{Se}\right)$ in samples. Preparation of standard solutions and dilution of samples for analysis were carried out in a class 100 clean laboratory. External calibrations were performed with daily prepared standards obtained by proper dilution of multi-elemental standard for ICP-MS (ICP-MS standard $N^{\circ} 3$ Perkin Elmer ${ }^{\circ}$, ICP-MS standard $\mathrm{N}^{\circ} 2$ from SCP SCIENCE $^{\circ}$ ) or a mono-elemental As standard (PlasmaCal, SCP SCIENCE ${ }^{\circ}$ ). An internal standard solution (containing 10 and $1 \mu \mathrm{g} \mathrm{L}-1$ of Ge and Tb respectively) was prepared by dilution of mono-elemental standards of Ge and Tb (PlasmaCal, SCP SCIENCE ${ }^{\circ}$. ${ }^{74} \mathrm{Ge}$ was chosen as an internal standard for As analyses to correct instrumental drifts. All sample analyses were preceded by a minimum of a five-point calibration curve spanning the entire concentration range of interest. All results were instrument blank corrected to account for any operational bias. The ongoing instrument performance was monitored by the analysis of continuing calibration verification standards. Daily analyses of the certified reference natural river water SLRS-5 or SLRS-6 (National 
Research Council, Canada) and analyses of the 3 solid CRM (MESS-2, TORT-2 and BCR-627) were carried out to check measurement accuracy and reproducibility of analytical calculations. Detection limits for ${ }^{75}$ As averaged $30 \mathrm{ng} \mathrm{L}^{-1}$.

As speciation analysis was performed by HPLC-ICP-MS. Instrumental settings and chromatographic conditions used throughout this work were described in Table 1 . Ion intensities at $m / z=75,77$ and 82 were monitored using a 'time-resolved' method from Chromera software (version 2, Perkin Elmer). No mathematical correction equation was used, but signals at $m / z=77$ and 82 were thoroughly monitored to insure the absence of the polyatomic interference with $\mathrm{Cl}$. The HPLC used in this study (Serie 200 Pump, Perkin Elmer) was equipped with an anion exchange column (Hamilton PRP-X100, length $25 \mathrm{~cm}$, particle size $10 \mu \mathrm{m}$, i.d. $4.1 \mathrm{~mm}$ ). Mobile phases were prepared by dissolving $\left(\mathrm{NH}_{4}\right)_{2} \mathrm{CO}_{3}$ salt (Sigma Aldrich) in Milli-Q water. This salt is commonly used with this type of anion exchange column (Wahlen et al., 2004). The final pH of the solution was adjusted to 9, by adding small amounts of either nitric acid or ammonia. The HPLC injection loop was cleaned using a $10 \% \mathrm{MeOH}$ solution. The outlet of the HPLC column was connected via PEEK capillary tubing $(0.125 \mathrm{~mm}$ i.d.) to a Rheodyne switching valve (6 ports, 2 positions, purchased by Perkin), which was in turn connected to the ICP-MS cyclonic nebulizer. Chromatographic conditions were optimized (composition of mobile phase, gradient, flowrate) to reach a rapid and sensitive analysis of 5 As species in 5 min. For calibration, the procedural blank chromatogram was subtracted. External calibration curves were used to quantify AsB, As(+III), $\mathrm{DMA}, \mathrm{MMA}, \mathrm{As}(+\mathrm{V})$ with the corresponding standards. Limits of detection were estimated using peak maximum height, and averaged $0.13 \mu \mathrm{g} \mathrm{L}^{-1}$ of As in diluted extracts, corresponding to $0.25 \mu \mathrm{g} \mathrm{g}^{-1}$ in sponge 217 samples. Arsenic speciation analyses were performed on diluted solutions obtained after a solid-liquid extraction, optimized in this study, lead on each dried sponge samples. For quantification in sponge samples and CRM, the chromatograms of the extraction blanks were systematically subtracted. In case of unknown As species, the calibration curves are similar for all As species analyzed in this work, as previously demonstrated 
was previously used for algae (Llorente-Mirandes et al., 2010) and in sponge samples (Taylor et al., 2012).

223 Standards used for As speciation were prepared daily from dilution of As(+III) and As(+V) stocks (1000 mg. $\mathrm{L}^{-1}$, 224 Absolute standard, Inc.) and organic As-mono-species solutions. The latter were prepared from salts of 225 arsenobetaine (AsB), sodium dimethylarsenite (DMA), disodium methylarsenate (MMA) (Sigma-Aldrich). 226 Species were identified by their retention times compared with standard compounds. Concentrations were 227 determined by comparing peak heights to known standards. The CRM BCR-627, certified for AsB and DMA, was 228 analyzed to check the accuracy of extraction and analytical methods. The TORT-2 was also analyzed for As 229 speciation and compared with literature data.

Statistical data treatments were carried out using XLSTAT (version 2014.05.5, Addinsoft, Paris, France). 231 One-way ANOVA tests were performed with a significance level of $p<0.05$ to estimate the inter-species 232 variability of As concentrations, between sites (Irish sponges), and between seasons (Mediterranean sponges).

\section{Results and discussion}

\subsection{Optimizations of analytical methodologies}

\subsubsection{Development of the mineralization method for total As analysis in sponges}

Nitric acid is often used to digest different types of marine organisms for trace elements analyses (shrimps, mussels, gastropods, worm, oysters) (Taylor et al., 2012; Zhang et al., 2015), even for freshwater sponges (Schaeffer et al., 2006). A two-steps method using $\mathrm{HNO}_{3}$ and then $\mathrm{H}_{2} \mathrm{O}_{2}$ was also reported in aquatic organisms such as algae, fishes, bivalves, crabs, and shrimps (Hong et al., 2014; Llorente-Mirandes et al., 2010), as well as 241 in sponges and associated bacteria (Keren et al., 2017). In order to select the best digestion procedure for As 242 determination in marine sponges, an optimization was carried out on a Haliclona fulva sample. Mineralization protocols were developed on about $100 \mathrm{mg}$ of dried sponge sample. The different methods and their results are presented in Table 1A (supplementary information). Protocols without microwaves have been rapidly 
245 abandoned because they resulted in jelly solutions, low As recoveries or results with a poor reproducibility.

246 Acid digestions assisted by microwaves without HF usually resulted in slightly lower As recovery than those 247 obtained with HF (around 20\% less). Sample microscope observations revealed undigested spicules in the 248 solution without HF (Fig. 3A, supplementary information). These protocols conduced to a partial mineralization 249 of sponge samples. In Antarctic Demospongiae (Sphaerotylus antarcticus, Kirkpatrikia coulmani and Haliclona 250 sp.) and in the Mediterranean species Petrosia ficiformis, the accumulation of pollutants ( $\mathrm{Cd}, \mathrm{Pb}$ and $\mathrm{Cu}$ ) was 251 demonstrated as being lower in the spicules than in the corresponding organic fraction even if spicules 252 represent about $80 \%$ of the biomass (Illuminati et al., 2016). This observation is in full agreement with our 253 results. Nevertheless, the As amount in Halicona fulva spicules cannot be neglected because it represents 254 around $20 \%$ of the total As. For sponges with siliceous skeletons, the use of HF is thus recommended. Higher As 255 concentrations were obtained with the use of $\mathrm{HNO}_{3} / \mathrm{HF}$ or $\mathrm{HCl} / \mathrm{HNO}_{3} / \mathrm{HF}$ mixtures. Nevertheless the use of $256 \mathrm{HNO}_{3} / \mathrm{HF}$ was preferred to prevent possible interferences onto the ${ }^{75} \mathrm{As}$ isotope coming from $\mathrm{HCl}$. Finally, the 257 chosen sample preparation procedure involving a microwave digestion has been performed using $5 \mathrm{ml}$ of $\mathrm{HNO}_{3}$ 258 and $2 \mathrm{ml}$ of $\mathrm{HF}$.

The optimized mineralization protocol was then applied to BCR-627 and TORT-2 marine biota CRMs as well as to MESS-2 sediment CRM. The obtained results for total As were in all cases in good agreement with the certified values, as shown in Table 2. Further applications of the developed procedure were performed on about $50 \mathrm{mg}$ of dried sponge.

\subsubsection{Development of the extraction method for sponge samples}

A very delicate step of the speciation analyses is the chemical extraction of As species as it has to guarantee the preservation of original chemical forms, avoiding oxidation, reduction or more generally any conversion in other chemical species. As reported by different authors (Lai et al., 1999; Schaeffer et al., 2006;

267 Ciardullo et al., 2010; Llorente-Mirandes et al., 2010; Taylor et al., 2012; Zhang et al., 2015), the most common 268 solid-liquid extraction for As species from biological materials include the use of $\mathrm{H}_{2} \mathrm{O}, \mathrm{MeOH}$ or a mixture of 
them, since AsB is the predominant specie in marine animals and it is soluble in both solvents (Leermakers et

270 al., 2006). A solution made of $2 \% \mathrm{HNO}_{3}$ was also used in chemical extraction for various aquatic organisms

271 (fishes, bivalves, crabs, shrimps) (Hong et al., 2014). $\mathrm{H}_{3} \mathrm{PO}_{4}$ was more often used for As extraction from soils

272 and sediments as it preserves the two redox states of As in these samples (Ellwood and Maher, 2003). In

273 sponges, extractions were performed either with $\mathrm{H}_{2} \mathrm{O}$ in freshwater organisms (revealing low recovery of $30 \%$ )

274 (Schaeffer et al., 2006), or with a mixture $\mathrm{H}_{2} \mathrm{O} / \mathrm{MeOH}$ (Shiomi et al., 1988; Yamaoka et al., 2001; Yamaoka et al., 275 2006; Keren et al., 2017). Extraction recoveries were not estimated in these last studies using methanol. Due to 276 lack of some data in these studies, an estimation of extraction recoveries obtained from sponges, can only be 277 performed with the results from Shiomi et al., 1988, using the ratio of the total water-soluble As divided by the 278 total As. These calculations gave extractions recoveries ranging from 19-56\% for three sponge species. The aim 279 of the present study was then to develop a more efficient extraction methods using different extracting 280 solutions.

The optimization of the extraction procedure was performed on three replicates of $H$. fulva sponge samples, using $10 \mathrm{~mL}$ of a given solution and $50 \mathrm{mg}$ of dried sponge sample. Extraction recoveries were calculated considering the total average As content of $29 \pm 5 \mathrm{mg} \mathrm{kg}^{-1}$ previously measured by ICP-MS on digested samples. Regardless of the tested extracting solution, extraction recoveries obtained in the present study were higher than $72 \%$ (Table 3) which are significantly higher than previous published results on sponges. The use of pure water as extracting solvent was not preferred because this method led to a lower extraction recovery $(72 \%)$ than those obtained with the other methods. This result is in accordance with previous studies demonstrating that some As species are not soluble in water (Shiomi et al., 1988). The extraction procedures which gave the best recoveries of total As were those involving $\mathrm{MeOH}$, reaching an extraction recovery of $86 \%$. Nevertheless the use of $\mathrm{MeOH}$ can lead to severe matrix effects, as already described in a previous study (Nam et al., 2010). Extraction methods using methanol revealed also a high variability of the results, as shown by high standard deviations (Table 3). Accounting uncertainties, similar 
results were reached for extracted As with $25 \% \mathrm{MeOH}$ or $0.6 \mathrm{~mol} \mathrm{~L}^{-1} \mathrm{H}_{3} \mathrm{PO}_{4}$ as extractants. Even if extractions performed with $25 \% \mathrm{MeOH}$ revealed a highest extraction recovery (86\%), this method was not retained due to possible analytical discrepancies and higher variabilities of the results. The $0.6 \mathrm{~mol} \mathrm{~L}^{-1} \mathrm{H}_{3} \mathrm{PO}_{4}$ solutions was selected because it appeared to be the best compromise: a good extraction recovery $81 \%$ (close to the $86 \%$ obtained with $25 \%$ of $\mathrm{MeOH}$ ) and a good reproducibility of the results (RSD=3\%). Considering that only a few studies have been published on As speciation in sponges, the choice of $\mathrm{H}_{3} \mathrm{PO}_{4}$ solution was also made in order not to lose the possible inorganic As species (the most toxic ones) possibly occurring in sponges samples, and to be able to preserve their chemical forms. The chosen extraction method was therefore applied to the selected CRMs. The extraction recoveries were found to be quite good, 106 and $97 \%$, for TORT-2 and BCR 627 respectively (Table 2). These results thus demonstrated the efficiency of the selected extraction solution.

\subsubsection{As speciation analyses}

Speciation analyses of the extracts allowed mainly AsB to be quantified whatever the extraction methods, AsB representing $57-114 \%$ of the extracted As (Table 3). The AsB concentration was overestimated using $50 \%$ $\mathrm{MeOH}$ as extractant, as shown by the anomalous high proportion of As from AsB in extracts (114\%). As previously demonstrated, AsB concentrations can be overestimated using $\mathrm{MeOH}$ ( $\mathrm{Nam}$ et al., 2010). Such as for extracted As, As from AsB concentrations revealed similar results with $25 \% \mathrm{MeOH}$ or $0.6 \mathrm{~mol} \mathrm{~L}^{-1} \mathrm{H}_{3} \mathrm{PO}_{4}$ as extractants, accounting uncertainties. The difference on extraction recovery obtained for As from AsB were thus not significant due to the high variability of the results obtained with $25 \% \mathrm{MeOH}$. Finally, the extraction method with $25 \% \mathrm{MeOH}$ was not retained due to possible analytical discrepancies and higher variabilities of the results. With the $0.6 \mathrm{~mol} \mathrm{~L}^{-1} \mathrm{H}_{3} \mathrm{PO}_{4}$ solutions, AsB represent $64 \%$ of the extracted As with a better precision.

Speciation analyses were performed then on CRMs and conduced to good speciation recoveries: $74 \%$ and $31498 \%$ for TORT-2 and BCR 627 respectively (Table 2), highlighting the efficiency of speciation analyses. 315 Measurements on the certified reference material BCR-627 gave a mean value of AsB equal to $4.5 \pm 0.5 \mathrm{mg} \mathrm{kg}^{-1}$ $316(n=6)$ and the occurrence of DMA just above the detection limit, in agreement with certified values. In TORT-2, 
317 the average AsB value was $13 \pm 5 \mathrm{mg} \mathrm{kg}^{-1}(n=4)$, in accordance with previously reported values (Suner et al., 318 2001; Wahlen et al., 2004). Two other As species occurred at low concentrations: DMA at $1.2 \pm 0.8 \mathrm{mg} \mathrm{kg}^{-1}$ and 319 another unknown As specie, named A, at $1.9 \pm 0.6 \mathrm{mg} \mathrm{kg}^{-1}$, eluting between DMA and MMA (retention time: $\mathrm{t}_{R}$ $320=2.5 \mathrm{~min})$. The DMA result is in agreement with the indicative value. These results on the two CRMs confirm 321 thus the efficiency of speciation analyses with accurate measurements of AsB.

\subsection{As bioaccumulation in sponges}

The variability of As content in sponges was estimated within the same specimen (intra-specimen variability), within the same sponge species (inter-specimen or intra-species variability), between different sampling sites or seasons, as well between different sponge species (inter-species variability).

The intra-specimen variability was evaluated analyzing at least 3 replicates of each sponge specimen (Table

2A, supplementary information). Each replicate underwent the whole sample preparation (i.e. microwave digestion and dilution). The total As content was highly variable within each specimen, with relative standard deviations (RSD) ranging from 8 to $36 \%$. This result highlights a certain inhomogeneity which may be related to the low amount of sponge samples weighted for digestion $(50 \mathrm{mg})$. specimens collected for each sponge species (Table 4). The variability, expressed with RSD, was usually around 10\%, but it reached 38\% for C. nucula in Feb. 2016. In Irish sponges inter-specimen variability was lower than in French samples (Table 4). Different authors reported RSD higher than $30 \%$ when evaluating intra-species

337 variability in total As and other trace elements found in sponge samples (Batista et al., 2014; Cebrian and Uriz, 2007). A relevant natural variation shall further be considered for these marine invertebrates. 
339 Variability of the total As content related to sampling site characteristics was also estimated. The variability of 340 As content and its species were estimated according to light conditions and the depth of the sampling (Fig. 1). 341 ANOVA tests revealed no significant difference between As content in $C$. damicornis specimens collected in the 342 cave center and those collected at the cave entrance; analogously no significant differences were found 343 between $C$. nucula specimens collected at different depths. For Irish sponges, ANOVA analyses revealed no 344 significant differences in As contents for the same Irish specie collected in Belfast and Killkieran Bay. ANOVA 345 analyses performed on Mediterranean sponges, showed no significant differences between As contents 346 measured in samples collected in two different period, except for $C$. damicornis sponges which showed 347 significant lower As content in September 2016. As-bioaccumulation is an integrative data over the sponge's 348 life. This explains in part the low temporal variations of As content in Mediterranean sponges between the two 349 sampling periods. Seasonal variations in As contents within the same species can be thus considered moderate 350 taking into account the inter-specimen variability.

A significant inter-species variability of total As content was shown, regardless of the considered sampling 352 period, and confirmed by ANOVA analysis. In France, C. damicornis sponges accumulate significantly higher As 353 amounts compared to other Mediterranean species (up to two times more). In Irish samples, As concentrations 354 were significantly lower than those measured in Mediterranean specimens (2 times lower). Differences in 355 accumulation efficiency between sponge species can be related to differences in morphological characteristics 356 but also to the age of the sponges. The different species have different growing rates. $H$. panicea and $H$. 357 perlevis are very fast growing compared to $C$. damicornis and C. nucula. The samples collected in the Irish 358 coasts belong to the same order (Suberitida), which could explain similar behavior in terms of As accumulation 359 while the Mediterranean sponges belong to the different orders Axinellida ( $C$. damicornis), Chondrosida ( $C$. 360 nucula), Haplosclerida ( $H$. fulva), and Bubarida (A. acuta). This study confirms that As concentration is 361 dependent on sponge species, as shown by the variable As contents found in the literature (Table 5). Sponges 362 accumulate more As than other marine organisms, which makes them suitable models for biomonitoring 
studies, as already proposed by Genta-Jouve et al., 2012. As accumulation was previously demonstrated to be higher in demosponges than in calcareous sponges (Yamaoka et al., 2001) and highly variable among different species of demosponges, as shown in the present study. Yamaoka et al. (2006) measured an As content equal to $6.1 \mathrm{mg} \mathrm{kg}^{-1}$ in Acanthella sp., which is slightly lower than values found in the present study. This difference is easily explained considering that the present study refers to As content in sponges measured after total digestion while Yamaoka et al. worked on water soluble fractions. Additionally, sponges may have very different morphological characteristics or microbiomes even when belonging to the same genus. In Haliclona $s p .$, previous study revealed As concentrations of $0.81 \mathrm{mg} \mathrm{kg}^{-1}$ in Haliclona $\mathrm{sp}$. white, $13 \mathrm{mg} \mathrm{kg}^{-1}$ in Haliclona permolis (Yamaoka et al., 2001), $1.03 \mathrm{mg} \mathrm{kg}^{-1}$ in Haliclona tenuiramosa (Venkateswara Rao et al., 2009) and between 1.5 and $8.5 \mathrm{mg} \mathrm{kg}^{-1}$ for Haliclona oculata (Aly et al., 2013). For these two species (Acanthella sp. and Haliclona sp.), the present study revealed higher As contents ranging from 29-44 $\mathrm{mg} \mathrm{kg}^{-1}$ (Table 4). Perez et al. (2005) measured also high As concentrations in another sponge species collected in the Mediterranean sea, Spongia officinalis (86.3-134.1 mg kg-1). Regarding Halichondria panicea, Vaskovsky et al. (1972) reported similar As concentrations $\left(6 \mathrm{mg} \mathrm{kg}^{-1}\right)$. But these results refer to As concentration measured in lipid extracts which is only a part of the total As content determined in this study. The present study confirms thus that As concentrations in sponges depends on the specific properties related to a particular sponge species.

\subsubsection{As bioaccumulation in sponges}

The Bio-Concentration Factor (BCF) and the Bio-Accumulation Factor (BAF) are useful and powerful tools in the interpretation of such results, since they give an idea of sponge behavior related to the surrounding environment and feeding habits. BCF represents the ratio between the As concentration found in biota and in the habitat, in this case the sediment. BAF represents the ratio between the As concentration found in biota and in the organism's diet, in our case seawater, since sponges are filter feeders (Gobas, 2001).

In this work, sediment collected from the French coast showed a constant As content for both sampling period: $7 \pm 2 \mathrm{mg} \mathrm{kg}^{-1}$ of As (measured on three sediment samples for each sampling period) while sediment 
samples collected from Kilkieran Bay and Greenisland show an As content of $7 \pm 2$ and $2.9 \pm 0.3 \mathrm{mg} \mathrm{kg}^{-1}$ respectively. These values are below the limit imposed by the principal environmental authorities for As in marine sediments (7.24 $\mathrm{mg} \mathrm{kg}^{-1}$, US EPA, 2006). Regarding sponges collected in Ireland, specimens coming from Kilkieran bay showed BCF close to 1 , while specimens of $H$. panicea and $H$. perlevis sponges collected in Belfast showed BCF of 2.1 and 3.5 respectively. BCF in Mediterranean sponges range from 3.6 to 12 . Similar values were reported for bivalves (6-19) (Negri et al., 2006) and were found to be higher than in other sponges (close to 1) (Mayzel et al., 2014). Extremely high As BCF of 477 was also previously measured in only one sponge species, Theonella swinhoei, which was explained by the presence of a particular bacterium (Mayzel et al., 2014). It is worth noticing that Theonella swinhoei is a slow growing and long lived sponge specie so As concentration may be also linked to the age of the sponge and thus responsible for the elevated BCF. The fact that most BCF were higher than 1 (except in Kilkieran Bay) proves that sponges are able to accumulate As at higher concentrations than their surrounding environment (sediment in our case), which means that there are additional biological processes involved in As accumulation.

As concentration in seawater used for the calculation of BAF in Mediterranean sponges was determined in a sample collected in Monaco and measured at the Environment Laboratories of the International Atomic Energy Agency. The average value found in seawater sample was $1.5 \pm 0.2 \mu \mathrm{g} \mathrm{L}^{-1}$ and it was used for BAF calculations because of the vicinity of the sampling site. This As content is in agreement with total As content of $1.3 \mu \mathrm{g} \mathrm{L}^{-1}$ previously measured in surface seawater from Mediterranean Sea (Cabon and Cabon, 2000). Mediterranean sponges BAF of As ranged between 15000 and 60000 , i.e. in the order of 4.2 to 4.8 for log BAF. For the calculation of BAF in Irish sponges, the average reference value for As in seawater was $2.5 \mu \mathrm{g} \mathrm{L}^{-1}$, as reported by Crompton and Crompton (1989). The BAF obtained were between 274 and 318 for samples collected in Kilkieran Bay and between 250 and 412 for samples collected in Greenisland, namely values 
Mediterranean sponges than Irish ones, but both sufficiently high to indicate that these organisms are efficient bioaccumulators of As.

Other BAFs reported in the literature for freshwater or marine organisms are in the range of $3<\log B A F<4$ for fishes, bivalves, shrimps, gastropods and mussels (Hong et al., 2014; Giusti and Zhang, 2002) algae and plankton (Chen et al., 2000; Mitra et al., 2012). In uncontaminated environments, As concentrations were measured in freshwater sponges (Ephydatia fluviatilis), water and sediments by Schaeffer et al., (2006) showing values of about $8.07 \mathrm{mg} \mathrm{kg}^{-1}, 1.1 \mu \mathrm{g} \mathrm{L}^{-1}$ and $3.6 \mathrm{mg} \mathrm{kg}^{-1}$ respectively (which is lower As contents than our Mediterranean sampling site but comparable with the Irish one). With these previous measurements on freshwater sponges, BAF and BCF calculations performed for As revealed: a BCF of 2.24 and a BAF of 7336 (log $\mathrm{BAF}=3.9)$. These results were slightly lower than those determined in our Mediterranean marine sponges but higher than results obtained for Irish samples. Nevertheless, it is quite difficult to compare these results due to different environmental conditions (freshwater or seawater). Concentrations of As in water, sediments and biota were previously suggested to increase with increasing salinity and BAF for As in other aquatic organisms might be slightly inversely proportional to salinity (Hong et al., 2014). In this study, BAF for As were higher in samples coming from the Mediterranean Sea (average salinity of about 38\%o) than those collected in Ireland (average salinity 34\%o) (Salaün et al., 2007; Tsimplis and Baker, 2000). However, the comparison is not easy due to the presence different sponge species, and the fact that TEs bioaccumulation in sponges was suggested to 427 differ according to sponge species (Batista et al., 2014; Mayzel et al., 2014). Factors affecting the differences in 428 the bioaccumulation are suggested to be mainly related to sponge species due to morphological characters like 429 spicules, fibers but also the microbial content. 
For all sponge species collected in this study, extraction recoveries vary from $49 \%$ to $105 \%$ (Table 4), 434 demonstrating the efficiency of the optimized extraction method for As. The variability of As extracted 435 amounts within the same species was quite moderate (ranging from 10 to 30\%). It can be easily noticed that 436 the extraction recoveries differ according to sponge species. The best As extraction recoveries (> $77 \%)$ were 437 obtained for $C$. nucula, H. panicea and H. pervelis. Extraction recoveries ranged between 51 and $69 \%$ for $H$. 438 fulva and $A$. acuta sponge species. Lowest extraction recoveries were obtained for $C$. damicornis (46-49 \%). 439 These low extraction recoveries may be explained by the occurrence of As organic species (for example, AsS), 440 not extracted with our method and which would be better extracted with methanol. For C. damicornis sponges, 441 further development of the extraction procedure would be necessary to increase the extraction recovery.

As speciation analyses were performed on extracts of sponge samples (Table 4). For each sponge species, speciation analyses were carried out on 3 sponge specimens. Significant differences on As speciation occur between the Irish and Mediterranean sponges (Fig. 2). Despite the fact that most of the As was successfully extracted in Irish sponges (>81\%), a large proportion of the extracted species was not identified/quantified 447 (speciation recoveries ranged from 52 to $66 \%$ ). Vaskovsky et al. (1972) reported a similar As concentrations in Halichondria panicea sponges, but measured in lipid extracts. This result may prove the occurrence of As rather under organic As species, probably those not identified in our study. For Mediterranean sponges, although the extraction recovery was generally lower than Irish samples (especially for $C$. damicornis), almost the totality of 451 extracted species were identified and quantified, with a speciation recovery between 79 and $119 \%$. Within the 452 same sponge species and the same sampling date, the variability of extracted As content and As speciation 453 related to sampling site characteristics was also estimated (Fig. 1). ANOVA analysis revealed no difference on 454 extracted As and As speciation for $C$. nucula sponges sampled at different depth; analogously no significant 455 difference in extracted As and As speciation was found for $C$. damicornis specimens collected at the center and 
entrance of the cave. Such as As bioaccumulation, As speciation in sponges is suggested to be mainly related to sponge species.

As speciation analysis in sponge extracts reveals the large occurrence of AsB (>29\% of the total As) and the presence of different As species at low concentrations: DMA, As(+V) (Fig. 2). Additionally, two unknown species were found: a first one eluting between DMA and MMA (only for C. nucula in Sep. 2016) and a second one eluting after $A s(+V)$. These results on As speciation in marine sponges are different from those obtained in freshwater sponge Ephydatia fluviatilis in which inorganic species were found to be dominant: $57 \%$ of $\mathrm{As}(+\mathrm{V})$, $20 \%$ of As(+III)), AsS (11\%), DMA (4\%) and undetected AsB (<1\%) (Schaeffer et al., 2006). In the present study, among minor As species, DMA accounted for about $10 \%$ of extracted As in Mediterranean sponges, (i.e. 4-8\% of the total As content) whereas this specie was not detected in Irish sponges at all. As(+V) was detected in all sponges' species, but it was possible to quantify it only for some of the Mediterranean specimens. This species represents about 5-9\% of the extracted As content (i.e. 1-5\% of the total As content). The unknown As species, named $B$ and eluting after $A s(+V)$ (retention time, $t_{R}=4.5 \mathrm{~min}$ ), presents a similar As concentration (close to $1 \mathrm{mg} \mathrm{kg}^{-1}$ ) regardless of the sponge species, representing between $5 \%$ and $15 \%$ of extracted As in Mediterranean and Irish sponges respectively (i.e. 2 and 15\% of the total As). The unknown As specie A, eluting between DMA and MMA ( $t_{R}=2.5 \mathrm{~min}$ ), occurs in A. acuta specimens but only in samples collected in September 2016, representing $6 \%$ of extracted As (i.e. $5 \%$ of the total As). Even if AsB is the main As species in H. fulva, A. acuta and C. nucula sponge species, it occurs in a lesser proportion in C. damicornis (31-44 \%), H. panicea (29$34 \%$ ), and H. pervelis (33-47 \%) (Fig. 2). Even though C. damicornis accumulates more As than the other sponge species, this sponge specie does not accumulate more AsB. This higher As content is thus related to other As species, probably other organic forms not extracted or not detected with the methodology used in the present study. The AsB predominance in A. acuta (86-94\% of As extracted or $48-55 \%$ of total As) is in accordance with the previous results on a sponge of the same genus ( $28 \%$ of the water soluble extract) (Yamaoka et al., 2006). Two AsS were also reported to occur in large amounts (22\% oxo-AsS-phosphate, $11 \%$ oxo-AsS-glycerol, and 
$39 \%$ of unknown As species). These other As species may coincide with the occurrence of unknown As species found in our study or other As species not extracted with our method, specifically the As specie B representing 7.5\% of extracted As. In H. fulva, AsB was also the predominant As-species (75-80\% of As extracted or $46-55 \%$ of total As), whereas in the same genus (H. permolis), the oxo-AsS-phosphate was identified (61\% of the water soluble extract) (Yamaoka et al., 2001 and 2006). The same authors also reported AsS as predominant As species in Halichondria sp., and a content of AsB between 9 and 32\% whereas AsB were reported dominant in another study (Shiomi et al., 1988). In the present study, H. panicea sponges from the same genus contained an AsB which accounts for 34 and $29 \%$ of total As, for samples collected in Kilkieran bay and Greenisland, respectively. All these results demonstrates that As speciation and the predominance of AsB or the AsS may not result only from sponge specie or genus characteristics. Yamaoka et al., (2001 and 2006) suggested that the different proportions of AsS may reflect the different symbionts living within sponges. This previous hypothesis would support: (1) the change of the predominant As-species within the same sponge species, and (2) the difference of As-bioaccumulation and biotransformation within a specific sponge species (C. damicornis, here) comparing to the others.

\subsection{Pathways of As bioaccumulation and biotransformation}

In surface seawater, As usually occurs under toxic inorganic species, mainly As(+V). Arsenic speciation

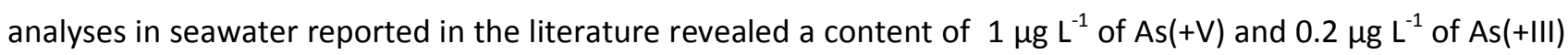
in the Mediterranean sea (Cabon and Cabon, 2000) and from 1.9 to $3 \mu \mathrm{g} \mathrm{L}^{-1}$ of $\mathrm{As}(+\mathrm{V})$ and $\mathrm{As}(+\mathrm{III})<\mathrm{LOD}$ in Irish seawater (Salaün et al., 2007). Sponges are efficient filter feeders, strongly accumulating As $(4<\log B A F<5)$. Due to As bioaccumulation and biotransformation (converting toxic inorganic As species in less-toxic organic species) within the sponge tissue, sponges may be a relevant tool for bioremediation of As-contaminated site, producing possible secondary metabolites of great interests (pharmaceuticals and bioactive compounds) under stressful environmental conditions (due to pollution). For instance, a polyarsenic organic compound showing antibacterial and antifungal properties was recently isolated from sponges (Mancini et al., 2006). The possible 
504 application of sponges in the field of environmental bioremediation has been proposed in previous studies with 505 different applications (Longo et al., 2010; Santos-Gandelman et al., 2014).

The main occurrence of AsB in osmoconformers such as sponges may be justified in waters characterized by high salinity because this molecule (as glycine-betaine) may serve to protect against osmolytic stress (Clowes and Francesconi, 2004; Caumette et al., 2012). Since AsB is also the least toxic form of arsenic, the production of such a molecule during a protecting process could be useful in the detoxification of As contaminated waters. Since no AsB occurs in seawater and low contents of inorganic As measured in sponges, biotransformation is responsible of these changes of As speciation. During their feeding process, sponges ingest water (where the dominant As-species is $\mathrm{As}(+\mathrm{V})$ ), and microorganisms (potentially containing organic As species). Two different pathways may be responsible of the As bioaccumulation and biotransformation within sponges: (1) a dietary route, through the feeding of microorganisms (phytoplankton) enriched by organic species; (2) and/or a waterborne route, i.e. a direct uptake from seawater and biotransformation within sponges.

Phytoplankton is considered as a major food source for the organisms of higher trophic levels, such as sponges; this autotrophic organism plays an important role in the distribution and biotransformation of As species in the marine environment (Rahman et al., 2012). Microorganisms which constitute the sponge's food, are known as producers (the first link of the food chain), contain high concentrations of As. AsB retained first 521 the attention because it is formed by organisms at low trophic levels and accumulated through the food chain 522 (Edmonds et al., 1993; Edmonds et al., 1997; Cullen and Reimer, 1989; Francesconi, 2010). Phytoplankton, 523 microalgae, bacteria or cyanobacteria are able to convert inorganic As into organic species through biological 524 processes (Azizur Rahman et al., 2012; Wang et al., 2015; Miyashita et al., 2016). For example, in 525 phytoplankton, inorganic arsenic is incorporated in cells where it is methylated and transformed into AsS via 526 adenosylation steps, possibly as a detoxification process (Caumette et al., 2012). The direct uptake of AsB527 enriched microorganisms by sponges seems thus to be unlikely because As speciation in producers (algae, 
phytoplankton) revealed the main occurrence of AsS and a low content of AsB (Grotti et al., 2010; LlorenteMirandes et al., 2010). Another dietary route would be the ingestion of AsS enriched microorganisms and the further conversion of AsS into AsB with sponge metabolisms or their symbionts organism. The unknown or undetected As species found in this study may be related to the occurrence of these AsS species.

The occurrence of AsB in sponges may be also related to microorganisms enriched with another As species, the (arsenoriboside) and ingested by the sponges. . As proposed by Caumette et al. (2012) for zooplankton, once sponges ingest phytoplankton, AsS may be degraded by associated bacterial communities, leading to the formation of AsB. The latter was also suggested to be produced within marine organisms from the transformation of arsenoribosides accumulated from their diet (Foster and Maher, 2016). Arsonioribosides would be thus another precursor of AsB formation. If the occurrence of $A s(+V)$ in seawater is recognized to be constant along time, the occurrence of micro-organisms is not continuous and can vary with seasons (e.g. phytoplankton dynamics vs nutrients in seawater). Because of the main occurrence of AsB within our sponge samples and the seasonal phytoplankton dynamic, the As biotransformation pathway via a dietary route it is rather unlikely to be the main process.

A waterborne route is the second hypothetic pathway for As bioaccumulation and transformation in sponges. After direct uptake of $\mathrm{As}(+\mathrm{V})$ from seawater, sponges might biotransform this inorganic As into AsB. Biological processes including methylation steps and conversion into AsB have previously been proposed for marine fishes (Zhang et al., 2016a; Zhang et al., 2016b) as well as for marine sponges (Yamaoka et al., 2006). For marine sponges, DMA was also proposed to be converted into AsS and further into AsB (Yamaoka et al., 2006). The unknown or undetected As species found in our sponge samples may account for the occurrence of AsS occuring in different proportions within sponges (34-60\%, orange parts in Fig. 2). The As biotransformation within sponges may be directly related to the sponge metabolism, but could also indirectly occur by the action of symbiotic micro-organisms (microalgae, bacteria). Symbiotic cyanobacteria can contain high As content and were already recognized as the source of the AsS in sponges (Yamaoka et al., 2001). 
Recently, As cycle in a Theonella swinhoei sponges was demonstrated to be largely driven by symbiotic bacteria

553 (Keren et al., 2017). This last result suggested rather the main implication of symbiont bacteria for As 554 biotransformation within sponges; but it is not obvious to confirm this pathway with our results. and western Irish coasts were investigated for their As bioaccumulation and biotransformation. Methodologies were optimized for As total determination and speciation in these marine organisms. The total As content was found to be very diverse according to sponge species and sampling sites, ranging between 6 and $77 \mathrm{mg} \mathrm{kg}^{-1}$. Bioaccumulation and bioconcentration factors revealed the great capabilities of sponges to accumulate this element with respect to concentration found in surrounding environment. As speciation showed predominance of AsB in all analyzed samples, in accordance with previous studies on marine organisms. The pathway for the conversion of $A s(+V)$ from seawater into $A s B$ in sponges is likely to be associated to the sponge metabolism or symbiont organisms. Finally, the outcomes of this study contribute to a better understanding of the distribution and metabolism of arsenic compounds in marine sponges.

\section{Acknowledgment}

The authors would like to express their deep gratitude to J.-P. Goudour for his technical assistance in our daily laboratory work, to D. Rodrigues and M. Nicolas for sponge sampling in France. The authors are grateful to F. Pannier and F. Séby for their precious advices for speciation analyses. The authors acknowledge the University of Nice Sophia Antipolis where all analyses were performed. A. M. Orani has benefited from a financial support from the University of Nice Sophia Antipolis and NUI Galway. The IAEA is grateful for the support provided by the Government of the Principality of Monaco to its Environment Laboratories. 
References

Aly, W., Williams, I.D., Hudson, M.D., 2013. Metal contamination in water, sediment and biota from a semi-enclosed coastal area. Environ. Monit. Assess. 185, 3879-3895. https://doi.org/10.1007/s10661-012-2837-0

Andrewes, P., Demarini, D.M., Funasaka, K., Wallace, K., Lai, V.W.M., Sun, H., Cullen, W.R., Kitchin, K.T., 2004. Do arsenosugars pose a risk to human health? The comparative toxicities of a trivalent and pentavalent arsenosugar. Environ. Sci. Technol. 38, 4140-4148. https://doi.org/10.1021/es035440f

Araújo, M.F., Conceição, A., Barbosa, T., Lopes, M.T., Humanes, M., 2003. Elemental composition of marine sponges from the Berlengas Natural Park, western Portuguese coast. X-Ray Spectrom. 32, 428-433. https://doi.org/10.1002/xrs.660

ATSDR, 2007. Toxicological Profile for Arsenic, U.S Public Health Service, Agency for Toxic Substances and Disease Registry. https://doi.org/http://dx.doi.org/10.1155/2013/286524

Rahman, M., Hasegawa, H., Peter Lim, R., 2012. Bioaccumulation, biotransformation and trophic transfer of arsenic in the aquatic food chain. Environ. Res. 116, 118-135. https://doi.org/10.1016/j.envres.2012.03.014

Barats, A., Féraud, G., Potot, C., Philippinini, V., Travi, Y., Durrieu, G., Dubar, M., Simler, R., 2014. Naturally dissolved arsenic concentrations in the Alpine/Mediterranean Var River watershed (France). Sci. Total Environ. 473-474, 422-436. https://doi.org/10.1016/J.SCITOTENV.2013.12.007

Batista, D., Muricy, G., Rocha, R.C., Miekeley, N.F., 2014. Marine sponges with contrasting life histories can be complementary biomonitors of heavy metal pollution in coastal ecosystems. Environ. Sci. Pollut. Res. 21, 5785-5794. https://doi.org/10.1007/s11356-014-2530-7

Beauchemin, D., 2008. Inductively coupled plasma mass spectrometry. Anal. Chem. 80, 4455-4486.

Bell, J.J., 2008. The functional roles of marine sponges. Estuar. Coast. Shelf Sci. 79, 341-353. https://doi.org/10.1016/j.ecss.2008.05.002

Benramdane, L., Bressolle, F., Vallon, J.-J., 1999. Arsenic speciation in humans and food products: a review. J. Chromatogr. Sci. 37, 330-44. https://doi.org/10.1093/chromsci/37.9.330

Brown, J.L., Kitchin, K.T., George, M., 1997. Dimethylarsinic acid treatment alters six different rat biochemical parameters: Relevance to arsenic carcinogenesis. Teratog. Carcinog. Mutagen. 17, 71-84. https://doi.org/10.1002/(SICI)1520-6866(1997)17:2<71::AID-TCM3>3.0.CO;2-B 
Cabon, J.Y., Cabon, N., 2000. Speciation of major arsenic species in seawater by flow injection hydride generation atomic absorption spectrometry. Fresenius. J. Anal. Chem. 368, 484-9. https://doi.org/10.1007/s002160000526

Caumette, G., Koch, I., Reimer, K.J., 2012. Arsenobetaine formation in plankton: a review of studies at the base of the aquatic food chain. J. Environ. Monit. 14, 2841. https://doi.org/10.1039/c2em30572k

Cebrian, E., Uriz, M.-J., Turon, X., 2007. Sponges as biomonitors of heavy metals in spatial and temporal surveys in northwestern mediterranean: multispecies comparison. Environ. Toxicol. Chem. 26, 2430-2439. https://doi.org/10.1897/07-292.1

Cebrian, E., Uriz, M.J., 2007. Contrasting effects of heavy metals on sponge cell behavior. Arch. Environ. Contam. Toxicol. 53, 552-558. https://doi.org/10.1007/s00244-006-0257-2

Chen, C.Y., Stemberger, R.S., Klaue, B., Blum, J.D., Pickhardt, P.C., Folt, C.L., 2000. Accumulation of heavy metals in food web components across a gradient of lakes. Limnol. Oceanogr. 45, 15251536. https://doi.org/10.4319/lo.2000.45.7.1525

Ciardullo, S., Aureli, F., Raggi, A., Cubadda, F., 2010. Arsenic speciation in freshwater fish: Focus on extraction and mass balance. Talanta 81, 213-221. https://doi.org/10.1016/j.talanta.2009.11.060

Clowes, L.A., Francesconi, K.A., 2004. Uptake and elimination of arsenobetaine by the mussel Mytilus edulis is related to salinity. Comp. Biochem. Physiol. - C Toxicol. Pharmacol. 137, 35-42. https://doi.org/10.1016/j.cca.2003.11.003

Crompton, T.R., Crompton, T.R., 1989. Chapter 8 - Organometallic compounds, in: Analysis of Seawater. pp. 336-359. https://doi.org/10.1016/B978-0-407-01610-1.50011-4

Cullen, W.R., Reimer, K.J., 1989. Arsenic speciation in the environment. Chem. Rev. 89, 713-764. https://doi.org/10.1021/cr00094a002

Denton, G.R.W., Concepcion, L.P., Wood, H.R., Morrison, R.J., 2006. Trace metals in marine organisms from four harbours in Guam. Mar. Pollut. Bull. 52, 1784-1804. https://doi.org/10.1016/j.marpolbul.2006.09.010

Edmonds, J.S., Francesconi, K.A., Stick, R. V, 1993. Arsenic compounds from marine organisms. Nat. Prod. Rep. 10, 421-428.

Edmonds, J.S., Shibata, Y., Francesconi, K. a, Rippingale, R.J., Morita, M., 1997. Arsenic transformations in short marine food chains studied by HPLC-ICP MS. Appl. Organomet. Chem. 11, 281-287. https://doi.org/10.1002/(sici)1099-0739(199704)11:4<281::aid-aoc581>3.3.co;2-j

Ellwood, M.J., Maher, W.A., 2003. Measurement of arsenic species in marine sediments by highperformance liquid chromatography-inductively coupled plasma mass spectrometry. Anal. Chim. Acta 477, 279-291. https://doi.org/10.1016/s0003-2670(02)01414-9 
Foster, S., Maher, W., 2016. Arsenobetaine and thio-arsenic species in marine macroalgae and herbivorous animals: Accumulated through trophic transfer or produced in situ? J. Environ. Sci. 49, 131-139. https://doi.org/10.1016/j.jes.2016.06.003

Francesconi, K.A., Sperling, M., 2005. Speciation analysis with HPLC-mass spectrometry: time to take stock. Analyst 130, 998. https://doi.org/10.1039/b504485p

Francesconi, K. a., 2010. Arsenic species in seafood: Origin and human health implications. Pure Appl. Chem. 82, 373-381. https://doi.org/10.1351/PAC-CON-09-07-01

Gazave, E., Carteron, S., Chenuil, A., Richelle-Maurer, E., Boury-Esnault, N., Borchiellini, C., 2010. Polyphyly of the genus Axinella and of the family Axinellidae (Porifera: Demospongiaep). Mol. Phylogenet. Evol. 57, 35-47. https://doi.org/10.1016/j.ympev.2010.05.028

Genta-Jouve, G., Cachet, N., Oberhänsli, F., Noyer, C., Teyssié, J.L., Thomas, O.P., Lacoue-Labarthe, T., 2012. Comparative bioaccumulation kinetics of trace elements in Mediterranean marine sponges. Chemosphere 89, 340-349. https://doi.org/10.1016/j.chemosphere.2012.04.052

Giusti, L., Zhang, H., 2002. Heavy metals and arsenic in sediments, mussels and marine water from Murano (Venice, Italy). Environ. Geochem. Health 24, 47-65. https://doi.org/10.1023/A:1013945117549

Gobas, F., 2001. Assessing Bioaccumulation Factors of Persistent Organic Pollutants in Aquatic FoodChains, in: Persistent Organic Pollutants: Environmental Behaviour and Pathways of Human Exposure. pp. 145-165. https://doi.org/10.1007/978-1-4615-1571-5_6

Grotti, M., Lagomarsino, C., Goessler, W., Francesconi, K.A., 2010. Arsenic speciation in marine organisms from Antarctic coastal environments. Environ. Chem. 7, 207-214. https://doi.org/10.1071/EN09131

Hong, S., Khim, J.S., Park, J., Son, H.S., Choi, S.D., Choi, K., Ryu, J., Kim, C.Y., Chang, G.S., Giesy, J.P., 2014. Species- and tissue-specific bioaccumulation of arsenicals in various aquatic organisms from a highly industrialized area in the Pohang City, Korea. Environ. Pollut. 192, 27-35. https://doi.org/10.1016/j.envpol.2014.05.004

Hsieh, M.W., Liu, C.L., Chen, J.H., Jiang, S.J., 2010. Speciation analysis of arsenic and selenium compounds by CE-dynamic reaction cell-ICP-MS. Electrophoresis 31, 2272-2278. https://doi.org/10.1002/elps.200900632

Hughes, M.F., 2002. Arsenic toxicity and potential mechanisms of action. Toxicol. Lett. 133, 1-16. https://doi.org/10.1016/S0378-4274(02)00084-X

Illuminati, S., Annibaldi, A., Truzzi, C., Scarponi, G., 2016. Heavy metal distribution in organic and siliceous marine sponge tissues measured by square wave anodic stripping voltammetry. Mar. Pollut. Bull. 111, 476-482. https://doi.org/10.1016/j.marpolbul.2016.06.098

Keren, R., Lavy, A., Ilan, M., 2016. Increasing the Richness of Culturable Arsenic-Tolerant Bacteria from 
Theonella swinhoei by Addition of Sponge Skeleton to the Growth Medium. Microb. Ecol. 71, 873-886. https://doi.org/10.1007/s00248-015-0726-0

Keren, R., Lavy, A., Mayzel, B., Ilan, M., 2015. Culturable associated-bacteria of the sponge Theonella swinhoei show tolerance to high arsenic concentrations. Front. Microbiol. 6, 1-11. https://doi.org/10.3389/fmicb.2015.00154

Keren, R., Mayzel, B., Lavy, A., Polishchuk, I., Levy, D., Fakra, S.C., Pokroy, B., Ilan, M., 2017. Spongeassociated bacteria mineralize arsenic and barium on intracellular vesicles. Nat. Commun. 8 , 14393. https://doi.org/10.1038/ncomms14393

KeyToNature, 2015. Marine Species Identification Portal [WWW Document]. URL http://speciesidentification.org/index.php (accessed 7.4.17).

Kucuksezgin, F., Gonul, L.T., Tasel, D., 2014. Total and inorganic arsenic levels in some marine organisms from Izmir Bay (Eastern Aegean Sea): A risk assessment. Chemosphere 112, 311-316. https://doi.org/10.1016/j.chemosphere.2014.04.071

Lai, V.W.M., Cullen, W.R., Ray, S., 1999. Arsenic speciation in scallops. Mar. Chem. 66, 81-89. https://doi.org/10.1016/S0304-4203(99)00025-0

Leermakers, M., Baeyens, W., De Gieter, M., Smedts, B., Meert, C., De Bisschop, H.C., Morabito, R., Quevauviller, P., 2006. Toxic arsenic compounds in environmental samples: Speciation and validation. TrAC - Trends Anal. Chem. 25, 1-10. https://doi.org/10.1016/j.trac.2005.06.004

Llorente-Mirandes, T., Ruiz-Chancho, M.J., Barbero, M., Rubio, R., López-Sánchez, J.F., 2010. Measurement of arsenic compounds in littoral zone algae from the Western Mediterranean Sea. Occurrence of arsenobetaine. Chemosphere 81, 867-875. https://doi.org/10.1016/j.chemosphere.2010.08.007

Longo, C., Corriero, G., Licciano, M., Stabili, L., 2010. Bacterial accumulation by the Demospongiae Hymeniacidon perlevis: A tool for the bioremediation of polluted seawater. Mar. Pollut. Bull. 60, 1182-1187. https://doi.org/10.1016/j.marpolbul.2010.03.035

Mancini, I., Guella, G., Frostin, M., Hnawia, E., Laurent, D., Debitus, C., Pietra, F., 2006. On the first polyarsenic organic compound from nature: Arsenicin $A$ from the new caledonian marine sponge Echinochalina bargibanti. Chem. - A Eur. J. 12, 8989-8994. https://doi.org/10.1002/chem.200600783

Mandal, B.K., Suzuki, K.T., 2002. Arsenic round the world: A review. Talanta 58, 201-235. https://doi.org/10.1016/S0039-9140(02)00268-0

Mayzel, B., Aizenberg, J., Ilan, M., 2014. The elemental composition of demospongiae from the Red Sea, Gulf of Aqaba. PLoS One 9. https://doi.org/10.1371/journal.pone.0095775

Mitra, N., Rezvan, Z., Seyed Ahmad, M., Gharaie Mohamad Hosein, M., 2012. Studies of Water Arsenic and Boron Pollutants and Algae Phytoremediation in Three Springs, Iran. Int. J. Ecosyst. 2, 32-37. 
Miyashita, S., Murota, D.C., Kondo, B.K., 2016. Arsenic metabolism in cyanobacteria. Environ. Chem. 13, 577-589.

Miyashita, S., Shimoya, M., Kamidate, Y., Kuroiwa, T., Shikino, O., Fujiwara, S., Francesconi, K.A., Kaise, T., 2009. Rapid determination of arsenic species in freshwater organisms from the arsenic-rich Hayakawa River in Japan using HPLC-ICP-MS. Chemosphere 75, 1065-1073. https://doi.org/10.1016/j.chemosphere.2009.01.029

Nam, S.H., Oh, H.J., Min, H.S., Lee, J.H., 2010. A study on the extraction and quantitation of total arsenic and arsenic species in seafood by HPLC-ICP-MS. Microchem. J. 95, 20-24. https://doi.org/10.1016/j.microc.2009.08.009

Nearing, M.M., Koch, I., Reimer, K.J., 2014. Complementary arsenic speciation methods: A review. Spectrochim. Acta - Part B At. Spectrosc. 99, 150-162. https://doi.org/10.1016/j.sab.2014.07.001

Negri, A., Burns, K., Boyle, S., Brinkman, D., Webster, N., 2006. Contamination in sediments, bivalves and sponges of McMurdo Sound, Antarctica. Environ. Pollut. 143, 456-467. https://doi.org/10.1016/j.envpol.2005.12.005

Olmedo, P., Pla, A., Hernandez, A.F., Barbier, F., Ayouni, L., Gil, F., 2013. Determination of toxic elements (mercury, cadmium, lead, tin and arsenic) in fish and shellfish samples. Risk assessment for the consumers. Environ. Int. 59, 63-72. https://doi.org/10.1016/j.envint.2013.05.005

Padovan, A., Munksgaard, N., Alvarez, B., McGuinness, K., Parry, D., Gibb, K., 2012. Trace metal concentrations in the tropical sponge Spheciospongia vagabunda at a sewage outfall: Synchrotron X-ray imaging reveals the micron-scale distribution of accumulated metals. Hydrobiologia 687, 275-288. https://doi.org/10.1007/s10750-011-0916-9

Pan, K., Lee, O.O., Qian, P.Y., Wang, W.X., 2011. Sponges and sediments as monitoring tools of metal contamination in the eastern coast of the Red Sea, Saudi Arabia. Mar. Pollut. Bull. 62, 11401146. https://doi.org/10.1016/j.marpolbul.2011.02.043

Patel, B., Balani, M., Patel, S., 1985. Sponge "sentinel" of heavy metals. Sci. Total Environ. 41, 143152.

Perez, T., Longet, D., Schembri, T., Rebouillon, P., Vacelet, J., 2005. Effects of 12 years' operation of a sewage treatment plant on trace metal occurrence within a Mediterranean commercial sponge (Spongia officinalis, Demospongiae). Mar. Pollut. Bull. 50, 301-309. https://doi.org/10.1016/j.marpolbul.2004.11.001

Phillips, D.J.H., 1990. Arsenic in aquatic organisms: a review, emphasising chemical speciation. Aquat. Toxicol. 16, 151-186.

Potot, C., Féraud, G., Schärer, U., Barats, A., Durrieu, G., Le Poupon, C., Travi, Y., Simler, R., 2012. Groundwater and river baseline quality using major, trace elements, organic carbon and $\mathrm{Sr}-\mathrm{Pb}-\mathrm{O}$ 
isotopes in a Mediterranean catchment: The case of the Lower Var Valley (south-eastern France). J. Hydrol. 472-473, 126-147. https://doi.org/10.1016/j.jhydrol.2012.09.023

Sakurai, T., 2002. Review: Biological effects of organic arsenic compounds in seafood. Appl. Organomet. Chem. 16, 401-405. https://doi.org/10.1002/aoc.325

Salaün, P., Planer-Friedrich, B., van den Berg, C.M.G., 2007. Inorganic arsenic speciation in water and seawater by anodic stripping voltammetry with a gold microelectrode. Anal. Chim. Acta 585, 312-322. https://doi.org/10.1016/j.aca.2006.12.048

Santos-Gandelman, J.F., Giambiagi-Demarval, M., Muricy, G., Barkay, T., Laport, M.S., 2014. Mercury and methylmercury detoxification potential by sponge-associated bacteria. Antonie van Leeuwenhoek, Int. J. Gen. Mol. Microbiol. 106, 585-590. https://doi.org/10.1007/s10482-0140224-2

Schaeffer, R., Francesconi, K.A., Kienzl, N., Soeroes, C., Fodor, P., Váradi, L., Raml, R., Goessler, W., Kuehnelt, D., 2006. Arsenic speciation in freshwater organisms from the river Danube in Hungary. Talanta 69, 856-865. https://doi.org/10.1016/j.talanta.2005.11.025

Shiomi, K., Aoyama, M., Yamanaka, H., Kikuchi, T., 1988. Chemical Forms of Arsenic in Sponges, SeaAnemones and Sea Hare. Comp. Biochem. Physiol. C-Pharmacology Toxicol. Endocrinol. 90, 361365.

Suner, M.A., Devesa, V., Munoz, O., Velez, D., Montoro, R., 2001. Application of column switching in high-performance liquid chromatography with on-line thermo-oxidation and detection by HGAAS and HG-AFS for the analysis of organoarsenical species in seafood samples. J. Anal. At. Spectrom. 16, 390-397. https://doi.org/10.1039/B007518N

Taylor, V.F., Jackson, B.P., Siegfried, M.R., Navratilova, J., Francesconi, K.A., Kirshtein, J., Voytek, M., 2012. Arsenic speciation in food chains from mid-Atlantic hydrothermal vents. Environ. Chem. 9, 130-138. https://doi.org/10.1071/EN11134

Tian, Y., Chen, M.-L., Chen, X.-W., Wang, J.-H., Hirano, Y., Sakamoto, H., Setsu, I., 2010. Arsenic speciation with gradient hydride generation interfacing liquid chromatography and atomic absorption spectrometry. J. Anal. At. Spectrom. 25, 48-54. https://doi.org/10.1039/B913198A

Tsimplis, M.N., Baker, T.F., 2000. Sea level drop in the Mediterranean Sea: An indicator of deep water salinity and temperature changes? Geophys. Res. Lett. 27, 1731-1734. https://doi.org/10.1029/1999GL007004

US EPA, 2006. Marine Sediment Screening Benchmarks, Region III.

Vaskovsky, V.E., Korotchenko, O.D., Kosheleva, L.P., Levin, V.S., 1972. Arsenic in the lipid extracts of marine invertebrates. Comp. Biochem. Physiol. Part B Comp. Biochem. 41, 777-784. https://doi.org/10.1016/0305-0491(72)90090-9

Venkateswara Rao, J., Srikanth, K., Pallela, R., Gnaneshwar Rao, T., 2009. The use of marine sponge, 
Haliclona tenuiramosa as bioindicator to monitor heavy metal pollution in the coasts of Gulf of Mannar, India. Environ. Monit. Assess. 156, 451-459. https://doi.org/10.1007/s10661-008-0497$x$

Wahlen, R., McSheehy, S., Scriver, C., Mester, Z., 2004. Arsenic speciation in marine certified reference materials - Part 2 . The quantification of water-soluble arsenic species by highperformance liquid chromatography-inductively coupled plasma mass spectrometry. J. Anal. At. Spectrom. 19, 876-882. https://doi.org/10.1039/b402482f

Wang, Y., Wang, S., Xu, P., Liu, C., Liu, M., Wang, Y., Wang, C., Zhang, C., Ge, Y., 2015. Review of arsenic speciation, toxicity and metabolism in microalgae. Rev. Environ. Sci. Bio/Technology 14, 427-451. https://doi.org/10.1007/s11157-015-9371-9

Weisz, J.B., Lindquist, N., Martens, C.S., 2008. Do associated microbial abundances impact marine demosponge pumping rates and tissue densities? Oecologia 155, 367-376. https://doi.org/10.1007/s00442-007-0910-0

Wu, X., Gao, M., Wang, L., Luo, Y., Bi, R., Li, L., Xie, L., 2014. The arsenic content in marketed seafood and associated health risks for the residents of Shandong, China. Ecotoxicol. Environ. Saf. 102, 168-173. https://doi.org/10.1016/j.ecoenv.2014.01.028

Yamaoka, Y., Carmona, M.L., Oclarit, J.M., Jin, K., Shibata, Y., 2006. Characterization of water-soluble organoarsenic compounds in marine sponges. Appl. Organomet. Chem. 20, 545-548. https://doi.org/10.1002/aoc

Yamaoka, Y., Carmona, M.L., Oclarit, J.M., Jin, K., Shibata, Y., 2001. Arsenic compounds in marine sponge (haliclona permolis, Halichondria japonica, Halichondria okadai and Haliclona sp. white) from Seto Inland Sea, Japan. Appl. Organomet. Chem. 15, 261-265. https://doi.org/10.1002/aoc.135

Zhang, W., Chen, L., Zhou, Y., Wu, Y., Zhang, L., 2016a. Biotransformation of inorganic arsenic in a marine herbivorous fish Siganus fuscescens after dietborne exposure. Chemosphere 147, 297304. https://doi.org/10.1016/j.chemosphere.2015.12.121

Zhang, W., Guo, Z., Zhou, Y., Chen, L., Zhang, L., 2016b. Comparative contribution of trophic transfer and biotransformation on arsenobetaine bioaccumulation in two marine fish. Aquat. Toxicol. 179, 65-71. https://doi.org/10.1016/j.aquatox.2016.08.017

Zhang, W., Guo, Z., Zhou, Y., Liu, H., Zhang, L., 2015. Biotransformation and detoxification of inorganic arsenic in Bombay oyster Saccostrea cucullata. Aquat. Toxicol. 158, 33-40. https://doi.org/10.1016/j.aquatox.2014.10.021 


\section{Figure captions}

\section{Figure 1.}

Results on total As in digested and extracted samples, and on As speciation for two sponge species (C. nucula and C. damicornis) collected under different environmental conditions (depth and light). The error bars represent the standard deviation calculated considering every replicate performed on each species $(n=3)$.

\section{Figure 2.}

Distribution of different As species in a) different sponge species collected during two sampling periods in France and b) different sponge species collected in two sampling sites in Ireland. 


\section{Tables}

Table 1. ICP-MS and HPLC-ICP-MS settings used for total As analyses and As speciation in marine sponge samples

\begin{tabular}{|c|c|c|}
\hline \multirow{2}{*}{\multicolumn{3}{|c|}{ ICP-MS Settings }} \\
\hline & & \\
\hline & RF power & $1550 \mathrm{~W}$ \\
\hline & Plasma gas flow & $15 \mathrm{~L} \mathrm{~min}^{-1}$ \\
\hline & Auxiliary gas flow & $1.1 \mathrm{~mL} \mathrm{~min}-1$ \\
\hline & Carrier gas flow & $0.9 \mathrm{~L} \mathrm{~min}^{-1}$ \\
\hline & Nebulizer & quartz concentric \\
\hline & Spray chamber & cyclonic \\
\hline & Interface & Pt sampling and skimmer cones \\
\hline & Analytical mass (m/z) & $75,77,82,74$ \\
\hline \multicolumn{3}{|l|}{ HPLC conditions } \\
\hline & Column (anion exchange) & Hamilton PRP-X100 \\
\hline & Column temperature & $20^{\circ} \mathrm{C}$ \\
\hline & Injection volume & $250 \mu \mathrm{L}$ \\
\hline & Mobile phase A & $5 \mathrm{mM}\left(\mathrm{NH}_{4}\right)_{2} \mathrm{CO}_{3} \mathrm{pH}=9$ \\
\hline & Mobile phase B & $70 \mathrm{mM}\left(\mathrm{NH}_{4}\right)_{2} \mathrm{CO}_{3} \mathrm{pH}=9$ \\
\hline & Flow rate & $2 \mathrm{~mL} \min ^{-1}$ \\
\hline & Gradient programme & $0-2 \min : 100 \% A$ \\
\hline & & $3-6 \min : 100 \% \mathrm{~B}$ \\
\hline & & 7-10 min: $100 \% A$ \\
\hline
\end{tabular}


Table 2. Total As and As speciation results for three CRMs: BCR-627, TORT-2 and MESS-2. Extracted As concentrations were determined by ICP-MS and AsB concentrations by HPLCICP-MS. * and ** represent reference values given by *Sunner et al., 2001 and **Wahlen et al., 2004.

\begin{tabular}{|c|c|c|c|c|}
\hline \multicolumn{2}{|c|}{ Certified Reference Materials } & \multirow{2}{*}{$\begin{array}{c}\text { TORT-2 } \\
22 \pm 2(n=6)\end{array}$} & \multirow{2}{*}{$\begin{array}{c}\text { BCR-627 } \\
5.2 \pm 0.5(n=4)\end{array}$} & \multirow{2}{*}{$\begin{array}{c}\text { MESS-2 } \\
19.2 \pm 1.1(n=4)\end{array}$} \\
\hline \multirow{3}{*}{$\begin{array}{l}\text { Microwave } \\
\text { digested } \\
\text { solutions }\end{array}$} & Total As (mg kg-1) & & & \\
\hline & Certified value & $21.6 \pm 1.8$ & $4.8 \pm 0.3$ & $20.7 \pm 0.8$ \\
\hline & Recovery (\%) & 102 & 108 & 92 \\
\hline \multirow{8}{*}{$\begin{array}{l}\text { Extracted } \\
\text { solutions }\end{array}$} & Extracted As (mg kg-1) & $23 \pm 4(n=3)$ & $4.6 \pm 0.3(n=6)$ & \\
\hline & Extraction recovery (\%) & 106 & 97 & \\
\hline & As from AsB (mg kg-1) & $13 \pm 5(n=4)$ & $4.5 \pm 0.5(n=6)$ & \\
\hline & Certified value & $\begin{array}{l}13.8 \pm 0.2^{*} \\
14.3 \pm 1.1^{* *}\end{array}$ & $3.9 \pm 0.2$ & \\
\hline & As from DMA (mg kg-1) & $1.2 \pm 0.8(n=4)$ & $0.1<c<0.3$ & \\
\hline & Certified value & $\begin{array}{l}0.97 \pm 0.05^{*} \\
0.84 \pm 0.10^{* *}\end{array}$ & $0.15 \pm 0.02$ & \\
\hline & As from unknown peak & $1.9 \pm 0.6(n=4)$ & - & \\
\hline & Speciation recovery (\%) & 74 & 98 & \\
\hline
\end{tabular}

Table 3. Extracted As concentrations and As speciation results obtained using different extraction methods on a pool of $H$. fulva sponges. Extracted As concentrations were determined by ICP-MS and AsB concentrations by HPLC-ICPMS. Extraction recoveries were calculated on the average total As content of $29 \pm 5 \mathrm{mg} \mathrm{kg}^{-1}$.

\begin{tabular}{|c|c|c|c|c|c|c|c|c|}
\hline \multirow[b]{2}{*}{$\mathrm{H}_{2} \mathrm{O}$} & \multicolumn{3}{|c|}{$\begin{array}{l}\text { Extracted As } \\
\left(\mathrm{mg} \mathrm{kg}^{-1}\right)\end{array}$} & \multirow{2}{*}{$\begin{array}{c}\begin{array}{c}\text { Extraction } \\
\text { recovery (\%) }\end{array} \\
72\end{array}$} & \multicolumn{3}{|c|}{$\begin{array}{l}\text { As from AsB } \\
\left(\mathrm{mg} \mathrm{kg}^{-1}\right)\end{array}$} & \multirow{2}{*}{$\begin{array}{c}\begin{array}{c}\text { As from AsB in } \\
\text { extracts (\%) }\end{array} \\
67\end{array}$} \\
\hline & 21 & \pm & 3 & & 14 & \pm & 3 & \\
\hline МeOH 50\% & 21 & \pm & 2 & 72 & 24 & \pm & 3 & 114 \\
\hline МeOH 25\% & 25 & \pm & 1 & 86 & 19 & \pm & 3 & 76 \\
\hline $\mathrm{H}_{3} \mathrm{PO}_{4} 0.3 \mathrm{~mol} \mathrm{~L}^{-1}$ & 20 & \pm & 3 & 69 & 13.0 & \pm & 0.8 & 65 \\
\hline $\mathrm{H}_{3} \mathrm{PO}_{4} 0.6 \mathrm{~mol} \mathrm{~L}^{-1}$ & 23.5 & \pm & 0.7 & 81 & 15.2 & \pm & 0.8 & 64 \\
\hline $\mathrm{H}_{3} \mathrm{PO}_{4} 1 \mathrm{~mol} \mathrm{~L}^{-1}$ & 24.2 & \pm & 0.5 & 83 & 13.9 & \pm & 0.8 & 57 \\
\hline
\end{tabular}


Table 4. Summary of As speciation results obtained for different sponges species sampled between February and November 2016 in three sites located in western Europe.

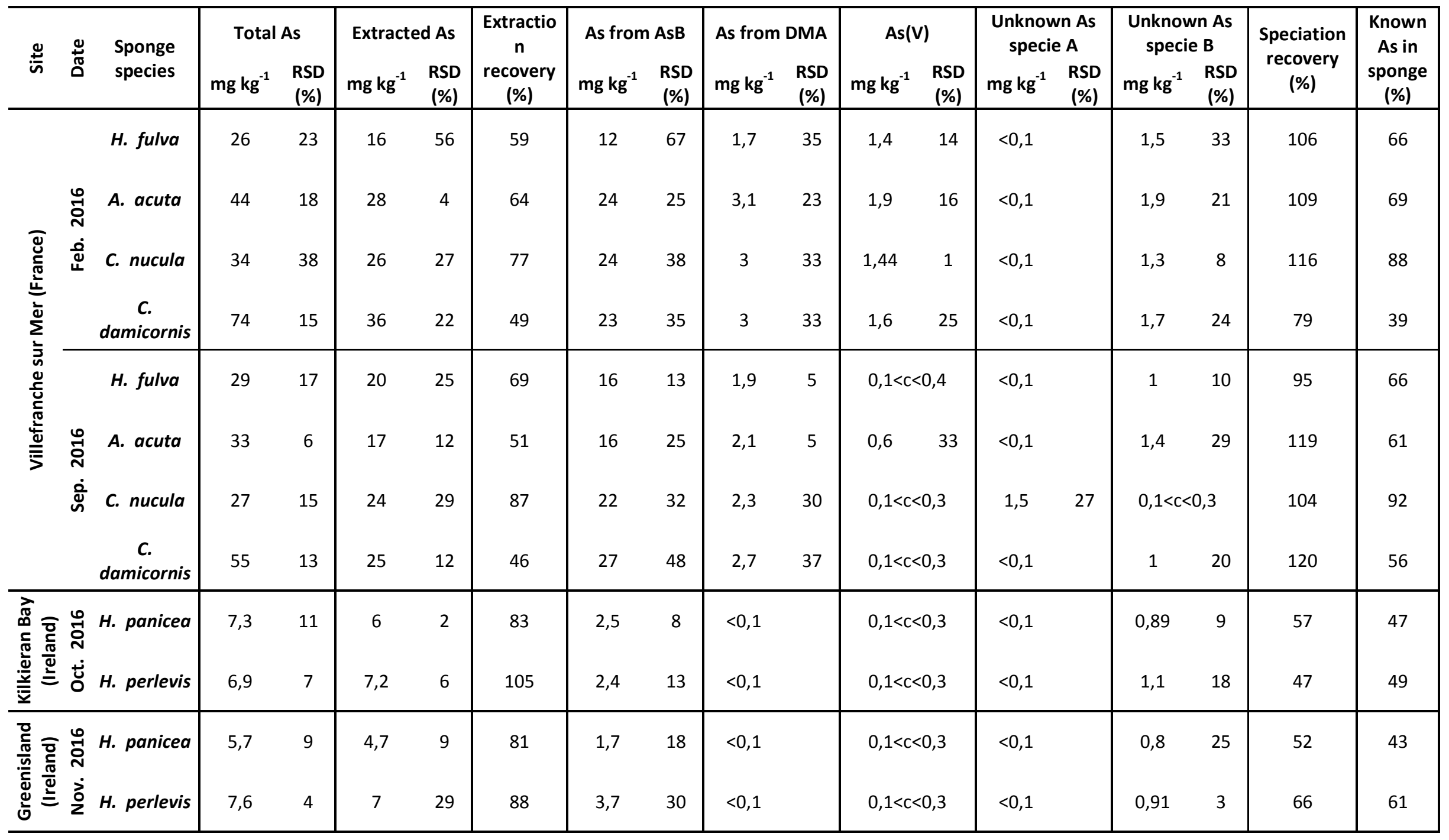


Table 5. Summary of literature data available on total As and its speciation in sponges. Total As results refer to total content in dried sample, unless otherwise stated.

\begin{tabular}{|c|c|c|c|c|c|c|}
\hline \multirow{2}{*}{ Sponge specie } & \multirow{2}{*}{ Sampling location } & \multirow{2}{*}{$\begin{array}{l}\text { Total As } \\
\left(\mathrm{mg} \mathrm{kg}^{-1}\right)\end{array}$} & \multicolumn{3}{|c|}{ As concentration ( $\mathrm{mg} \mathrm{kg}^{-1}$ ) } & \multirow{2}{*}{ Reference } \\
\hline & & & AsB & AsS & Others & \\
\hline Hymeniacidon heliophila & \multirow{2}{*}{$\begin{array}{c}\text { Guanabara Bay, } \\
\text { Brazil }\end{array}$} & $4.6-8.1$ & & & & \multirow{2}{*}{ Batista et al., 2014} \\
\hline Paraleucilla magna & & $1.2-2.6$ & & & & \\
\hline Haliclona oculata & Poole harbor, UK & $1.5-8.5$ & & & & Aly et al., 2013 \\
\hline $\begin{array}{l}\text { Spheciospongia } \\
\text { vagabunda }\end{array}$ & $\begin{array}{c}\text { Darwin Harbour, } \\
\text { Aurstralia }\end{array}$ & $10.1-56.4$ & & & & Padovan et al., 2012 \\
\hline Hyrtios erectus & \multirow{9}{*}{ Red Sea, Saudi Arabia } & $15-63.9$ & & & & \multirow{9}{*}{ Pan et al., 2011} \\
\hline Hyrtios sp. & & 2.30 & & & & \\
\hline Stylissa carteri & & $7.5-10.7$ & & & & \\
\hline Chalinula sp. & & $13.7-22.1$ & & & & \\
\hline Xestospongia testudinaria & & $20.7-42.2$ & & & & \\
\hline Phyllospongia papyracea & & 8.0 & & & & \\
\hline Amphimedon sp. & & 11.2 & & & & \\
\hline Spongia arabica & & 106.1 & & & & \\
\hline Spheciospongia inconstans & & 15.0 & & & & \\
\hline Haliclona tenuiramosa & Gulf of Mannar, India & $0.32-1.09$ & & & & Rao et al., 2009 \\
\hline Petrosia testudinaria & Gulf of Mannar, India & 2.30 & & & & Rao et al., 2006 \\
\hline Thorecta sp. & \multirow{13}{*}{$\begin{array}{l}\text { Bohol Sea, } \\
\text { Philippines }\end{array}$} & $6.2^{*}$ & 3.0 & 2 & 1.2 & \multirow{13}{*}{ Yamaoka et al., 2006} \\
\hline Dysidea sp. & & $24.8^{*}$ & 15.2 & 1.4 & 8.1 & \\
\hline Theonella sp. & & $157.0^{*}$ & 136.6 & 2.21 & 18.2 & \\
\hline Acanthella sp. & & $6.1 *$ & 1.7 & 2.0 & 2.4 & \\
\hline Phyllospongia sp. & & $4.4^{*}$ & 1.5 & 2.12 & 0.7 & \\
\hline Aaptos sp. & & $112.5^{*}$ & 98.1 & 0.25 & 14.2 & \\
\hline Biemna fortis & & $1.0^{*}$ & 0.13 & 0.15 & 0.8 & \\
\hline Jaspis sp. & & $6.1^{*}$ & 0.6 & 3.7 & 1.7 & \\
\hline Subertes sp. & & $10.3^{*}$ & 1.7 & 7.4 & 1.1 & \\
\hline Haliclona permolis & & $13 *$ & 3.3 & 9.9 & 0.5 & \\
\hline Halichondria japonica & & $3.4^{*}$ & 1.1 & 1.6 & 0.8 & \\
\hline Haliclona sp. white & & $0.8^{*}$ & 0.2 & 0.5 & 0.2 & \\
\hline Halichondria okadai & & $5.5^{*}$ & 0.5 & 4.5 & 0.5 & \\
\hline Ephydatia fluviatilis & $\begin{array}{c}\text { Danube river, } \\
\text { Hungary }\end{array}$ & 8.07 & $<0.02$ & 0.29 & $\begin{array}{l}0.12 \\
(\mathrm{DMA})\end{array}$ & Schaeffer et al., 2006 \\
\hline Spongia officinalis & Marseille, France & $86.3-134.1$ & & & & Perez et al., 2005 \\
\hline
\end{tabular}




\begin{tabular}{|c|c|c|c|c|c|c|}
\hline Callispongia diffusa & \multirow{9}{*}{$\begin{array}{l}\text { Guam Island, } \\
\text { Pacific Ocean }\end{array}$} & $<0.01$ & & & & \multirow{9}{*}{ Denton et al., 2006} \\
\hline Cinachyra sp. & & $<0.01$ & & & & \\
\hline Clathria vulpina & & $<0.01$ & & & & \\
\hline Dysidea sp. & & $0.01-10.5$ & & & & \\
\hline Liosina cf. granularis & & $39.7-47.7$ & & & & \\
\hline Stylotella aurantium & & $0.01-6.42$ & & & & \\
\hline Unidentified sponge 1 & & 5.91-19.8 & & & & \\
\hline Unidentified sponge 2 & & 37.9 & & & & \\
\hline Unidentified sponge 3 & & $0.01-43.1$ & & & & \\
\hline Cliona viridis & \multirow{10}{*}{$\begin{array}{c}\text { Berlangas Islands, } \\
\text { Portugal }\end{array}$} & $25-32$ & & & & \multirow{10}{*}{ Araujo et al., 2003} \\
\hline Cliona celata & & $12-47$ & & & & \\
\hline Myriastra ananoora & & 73 & & & & \\
\hline Erylus discophorus & & $60-99$ & & & & \\
\hline Adocia sp. & & $16-21$ & & & & \\
\hline Spongia nitens & & $33-65$ & & & & \\
\hline Spongia agaricina & & $47-83$ & & & & \\
\hline Spongia officinalis & & $47-64$ & & & & \\
\hline Cacospongia scalaris & & $64-119$ & & & & \\
\hline Ircinia fasciculata & & $31-65$ & & & & \\
\hline Haliclona permolis & \multirow{4}{*}{$\begin{array}{l}\text { Seto Inland Sea, } \\
\text { Japan }\end{array}$} & $13.00^{*}$ & 3.34 & 9.2 & 0.52 & \multirow{4}{*}{$\begin{array}{l}\text { Yamaoka et al., } 2001 \\
\text { *water fraction }\end{array}$} \\
\hline Halichondria japonica & & $3.42^{*}$ & 1.10 & 1.54 & 0.78 & \\
\hline Halichondria okadai & & $5.50 *$ & 0.53 & 4.5 & 0.47 & \\
\hline Haliclona sp. white & & $0.81^{*}$ & 0.15 & 0.45 & 0.21 & \\
\hline Halichondria okadai & \multirow{3}{*}{ Chiba, Japan } & 6.80 & n.q. & & & \multirow{3}{*}{$\begin{array}{l}\text { Shiomi et al., } 1988 \\
\text { n.q. : not quantified }\end{array}$} \\
\hline Halichondria japonica & & 6.40 & & & & \\
\hline Spirastrella insignis & & 3.20 & n.q. & & n.q. & \\
\hline Halichondria panicea & Posiet Bay Japan & $6.4 * *$ & & & & $\begin{array}{l}\text { Vaskovsky et al., } 1972 \\
\text { **lipid extract }\end{array}$ \\
\hline
\end{tabular}




\section{FIGURES}

\section{Figure 1}
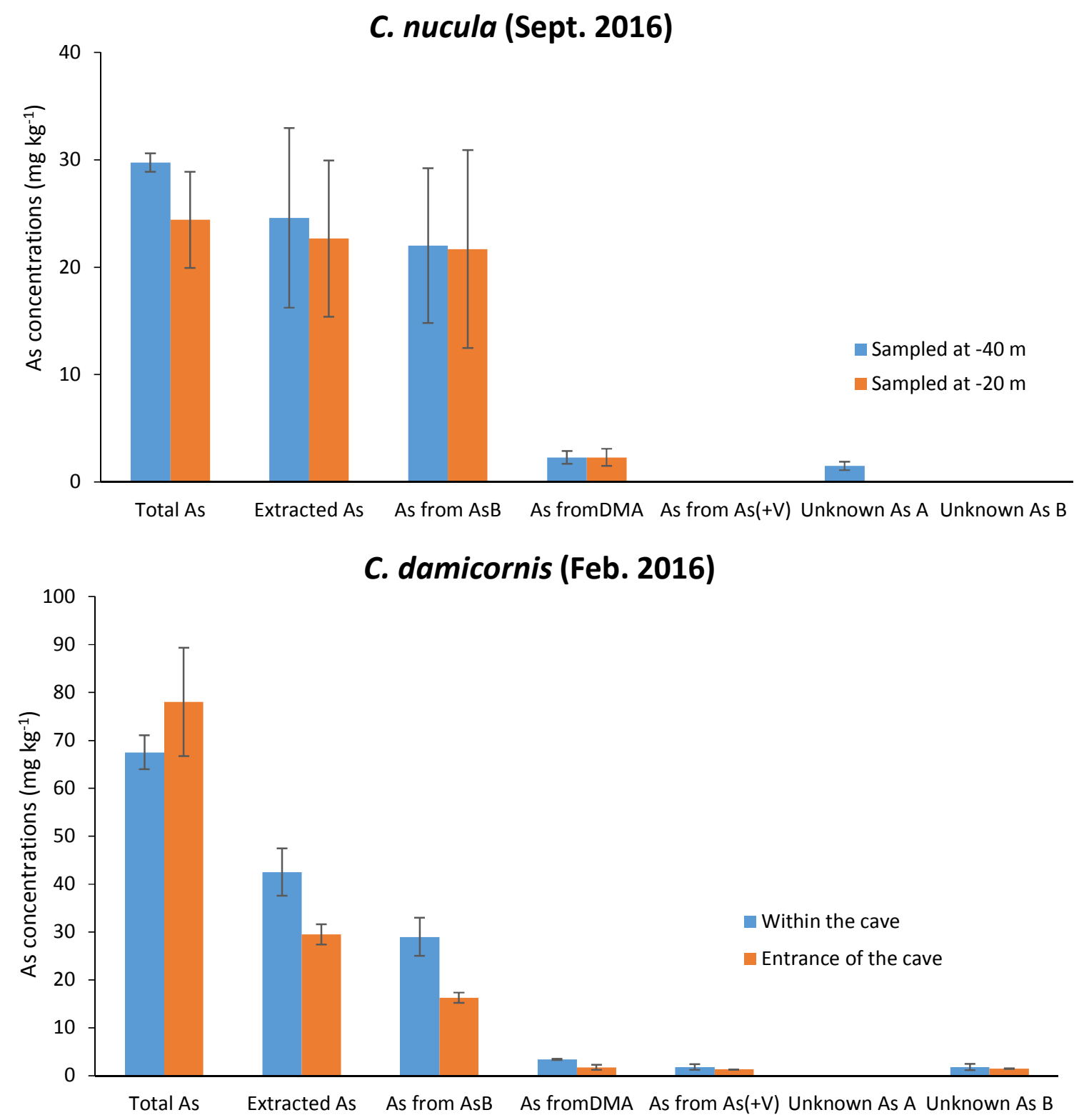


\section{Figure 2}

a)

H. fulva (Feb. 2016)

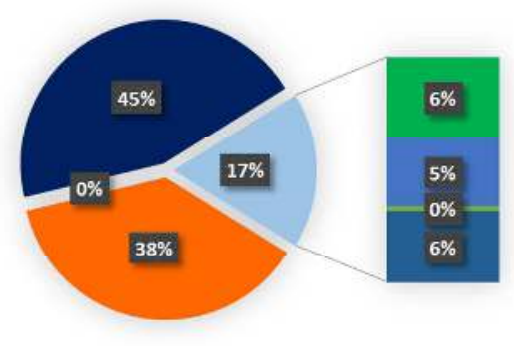

H. fulva (Sep. 2016)
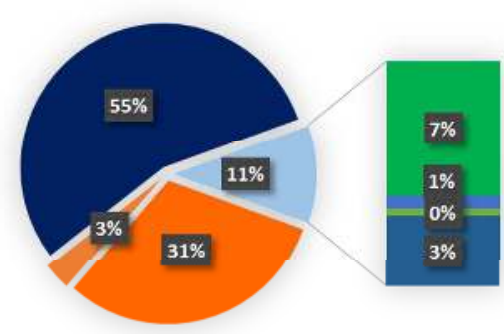

C. nucula (Feb. 2016)
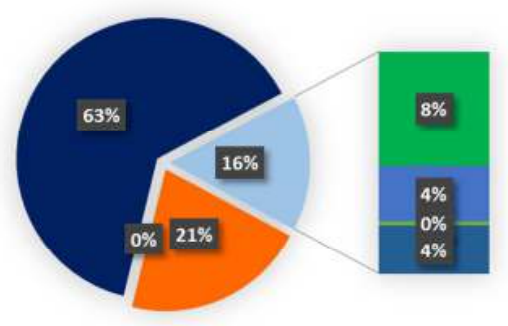

C. nucula (Sep. 2016)

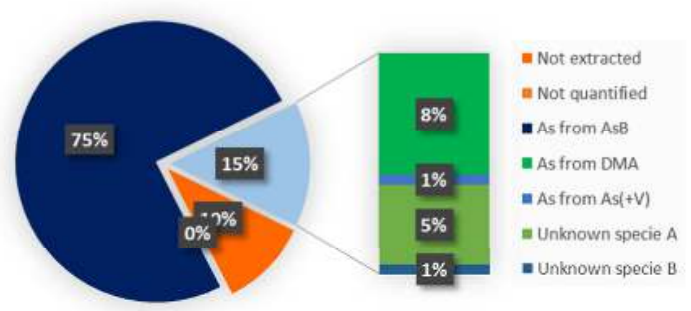

w Not quantified

- Unknown specie B

Not extracted

= Not quantified

- As from AsB

- As from DMA

- As from As(+V)

- Unknown specie A

- Unknown specie B
A. acuta (Feb. 2016)
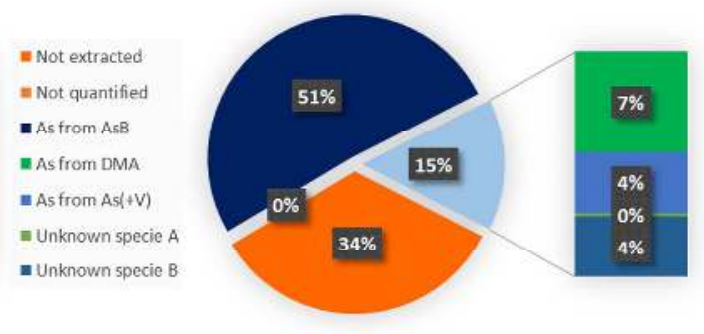

- Not extracted

= Not quantified

- As from AsB

-As from DMA

- As from As(t+V)

m Unknown specie A

- Unknown specie B

A. acuta (Sep. 2016)

wot extracted

- As from AsB

- As from DMA

- As from As( $+V$ )

w Unknown specie A
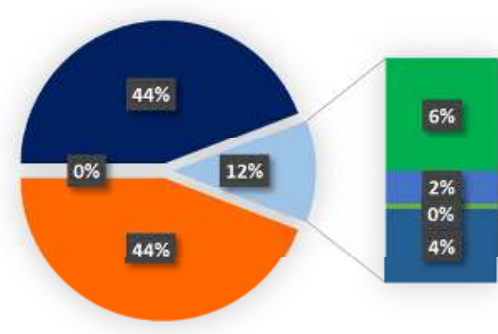

- Not extracted

in Not quantified

- As from AsB

in As from DMA

- As from As( $+V$ )

- Unknown specie $A$

- Unknown specie B
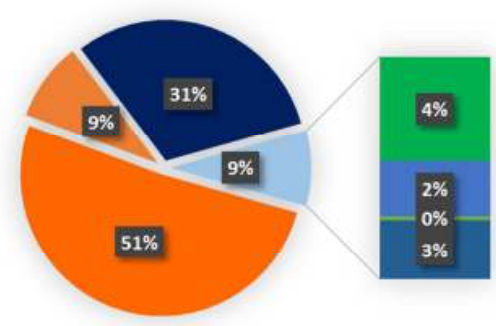

- Not extracted

= Not quantified

- As from AsB

- As from DMA

- As from As(+V)

- Unknown specie A

- Unknown specie B

\section{C. damicornis (Sep. 2016)}
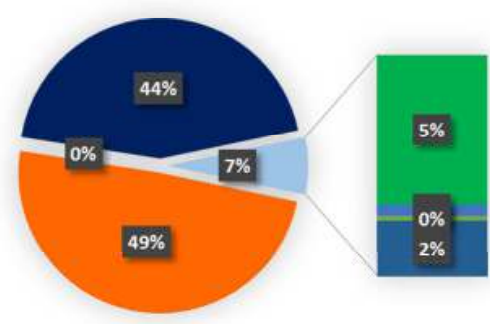

mot extracted

= Not quantified

- As from AsB

= As from DMA

- As from As(+V)

= Unknown specie A

- Unknown specie B 
b)

H. panicea (Kilkieran bay)

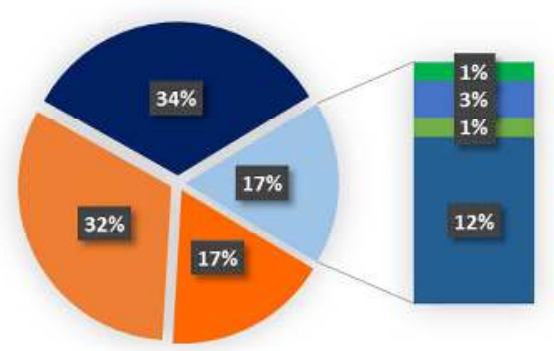

H. panicea (Greenisland)

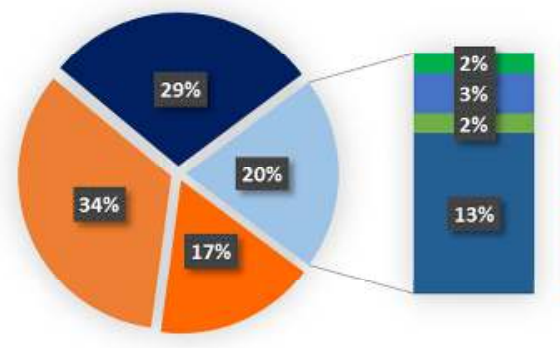

H. perlevis (Kilkieran bay)
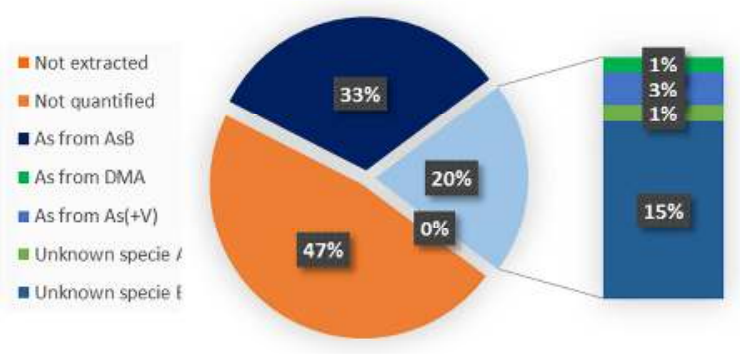

- Not extracted not quantified

- As from AsB

- As from DMA

- As from As(+V)

- Unknown specie $A$

- Unknown specie B 


\section{Highlights}

- The efficiency of $\mathrm{H}_{3} \mathrm{PO}_{4}$ as extractant for As speciation in sponges was demonstrated

- As bioaccumulation and speciation mainly depend on sponge species

- As speciation in sponges revealed the predominance of AsB

- Sponge itself or symbiont organisms are responsible of AsB formation

- Sponges are efficient tools for biomonitoring and bioremediation studies 